\title{
A Remarkable Difference That One Fluorine Atom Confers on the Mechanisms of Inactivation of Human Ornithine Aminotransferase by Two Cyclohexene Analogues of $\gamma$ - Aminobutyric Acid
}

Wei Zhu, ${ }^{\text {a }}$ Peter F. Doubleday, ${ }^{\mathrm{b}}$ Daniel S. Catlin, ${ }^{\mathrm{d}}$ Pathum M. Weerawarna, ${ }^{\mathrm{a}}$ Arseniy Butrin, ${ }^{\mathrm{d}}$ Sida Shen, ${ }^{\mathrm{a}}$ Zdzislaw Wawrzak, ${ }^{\mathrm{e}}$ Neil L. Kelleher, ${ }^{\mathrm{a}, \mathrm{b}}$ Dali Liu, ${ }^{\mathrm{d}}$ Richard B. Silverman*a,b,c

${ }^{a}$ Department of Chemistry, Chemistry of Life Processes Institute, Center for Molecular Innovation and Drug Discovery, and Center for Developmental Therapeutics, Northwestern University, Evanston, Illinois 60208, United States

b Department of Molecular Biosciences, Northwestern University, Evanston, Illinois 60208, United States

${ }^{c}$ Department of Pharmacology, Northwestern University, Chicago, Illinois 60611, United States

${ }^{\mathrm{d}}$ Department of Chemistry and Biochemistry, Loyola University Chicago, Chicago, Illinois 60660, United States

e Synchrotron Research Center, LS-CAT, Sector 21, Northwestern University, Lemont, IL 60439, United States 


\section{Table of Contents}

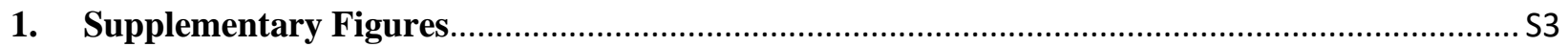

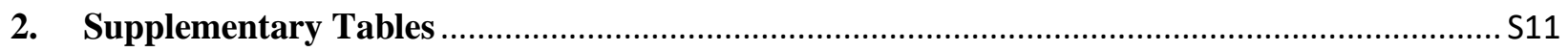

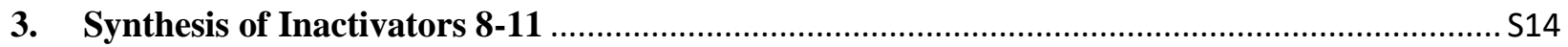

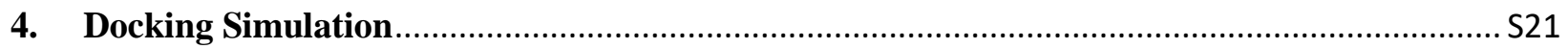

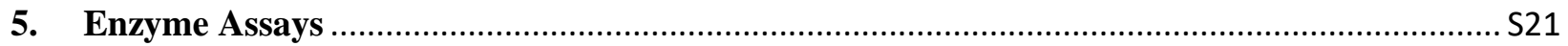

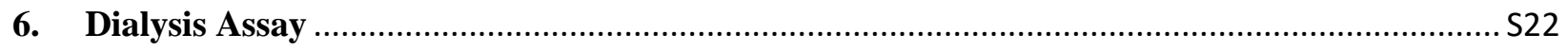

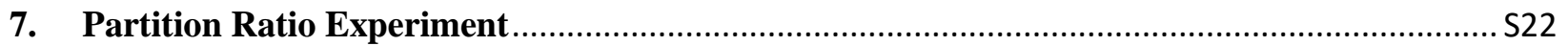

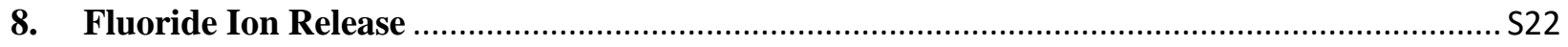

9. Intact Protein and Small Molecule Mass Spectrometry ….................................................. S22

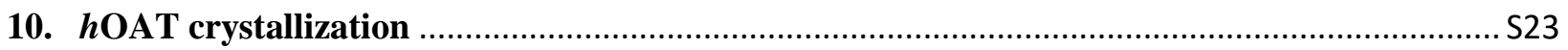

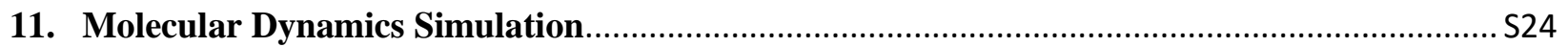

12. Electrostatic Potential (ESP) Charge Calculation .............................................................. S25

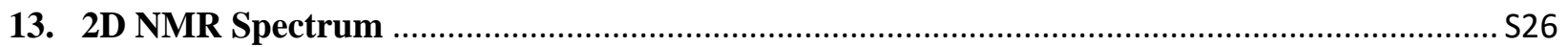

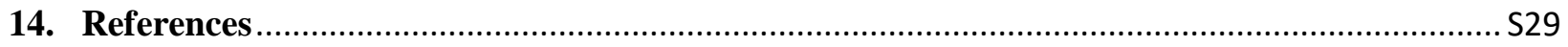




\section{Supplementary Figures}
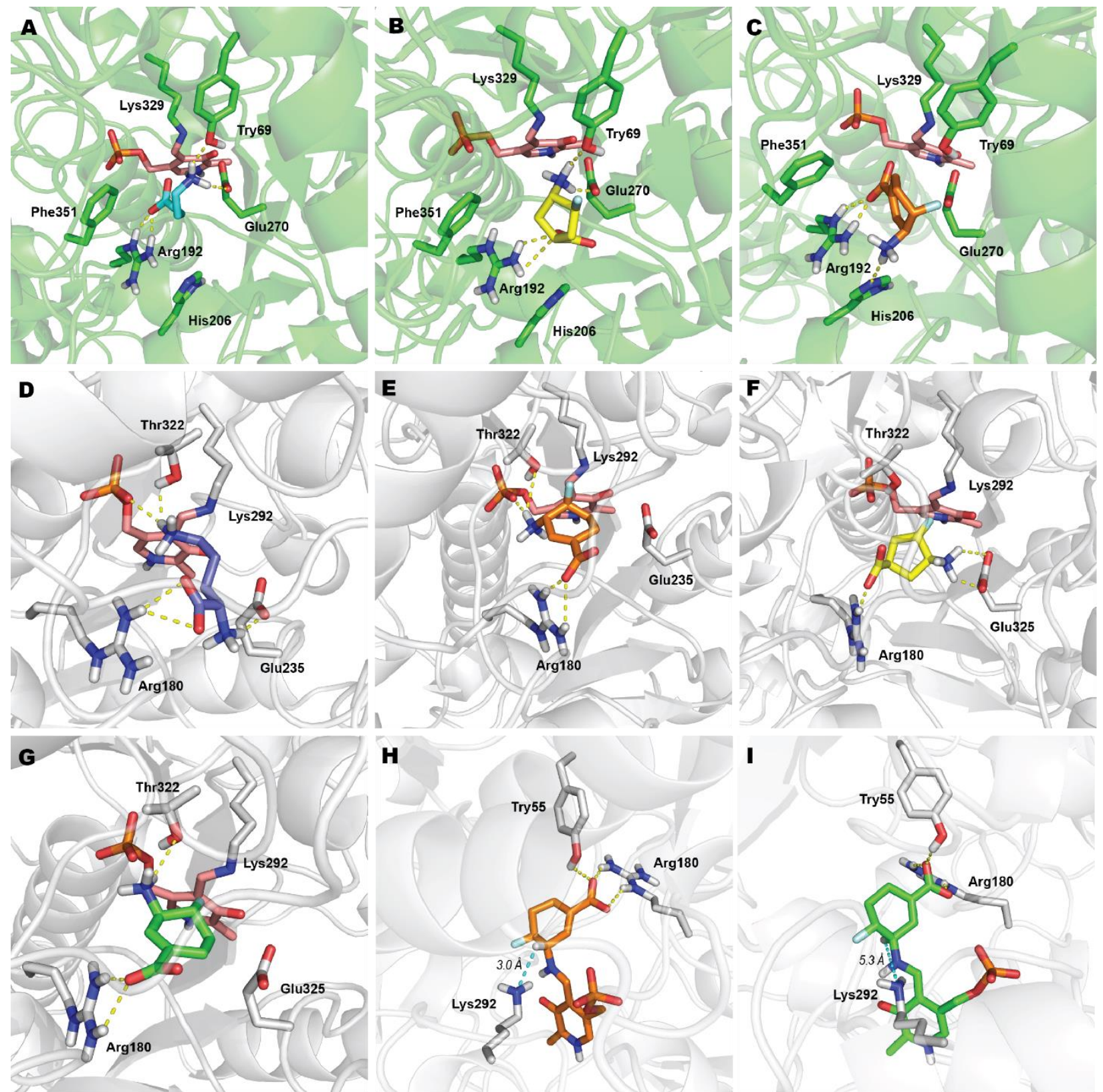

Figure S1. Molecular docking studies. (A) Molecular docking binding pose of $\gamma$-aminobutyric acid (blue) in the catalytic site of GABA-AT with PLP (pink) binding with Lys329. (B) Molecular docking binding pose of $\mathbf{1}$ in the catalytic site of GABA-AT with PLP (pink) binding with Lys329. (C) Molecular docking binding pose of 8 in the catalytic site of GABA-AT with PLP (pink) binding with Lys329. (D) Molecular docking binding pose of ornithine (slate) in the catalytic site of $h \mathrm{OAT}$ with PLP (pink) binding with Lys292. (E) Molecular docking binding pose of 8 (orange) in the catalytic site of $h \mathrm{OAT}$ with PLP (pink) binding with Lys292. (F) Molecular docking binding pose 
of 1 (yellow) in the catalytic site of $h$ OAT with PLP (pink) binding with Lys292. (G) Molecular docking binding pose of the 8-enantiomer (green) in the catalytic site of hOAT with PLP (pink) binding with Lys292 (H) Molecular docking binding pose of intermediate 12a (orange) in the catalytic site of hOAT. (I) Molecular docking binding pose of 12a-enantiomer (green) in the catalytic site of $h \mathrm{OAT}$.
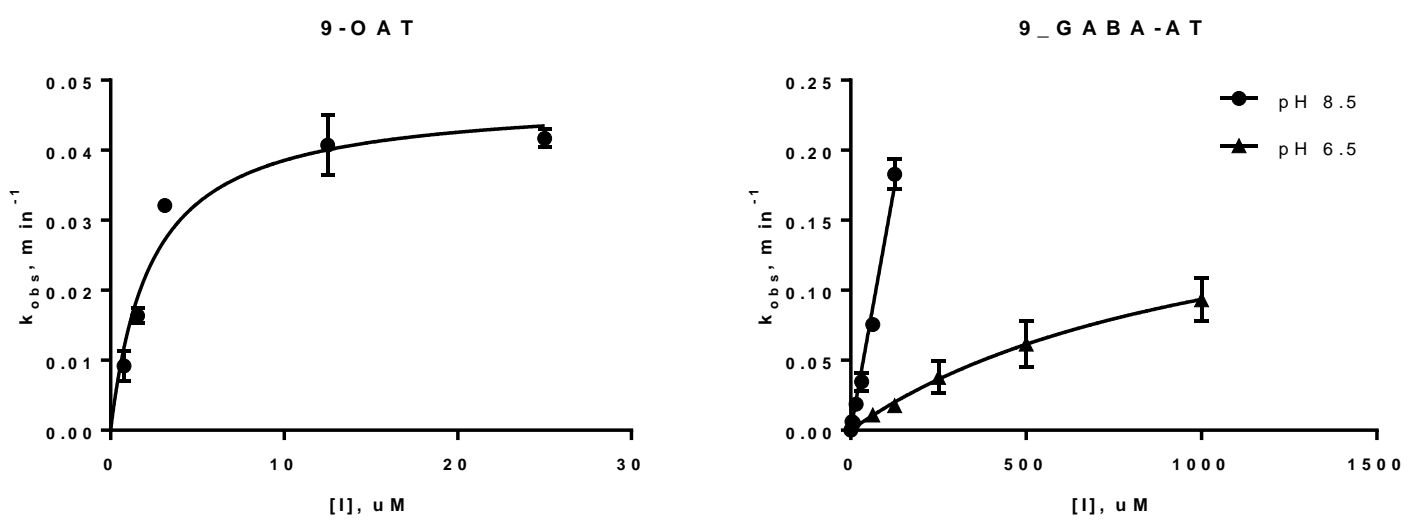

9

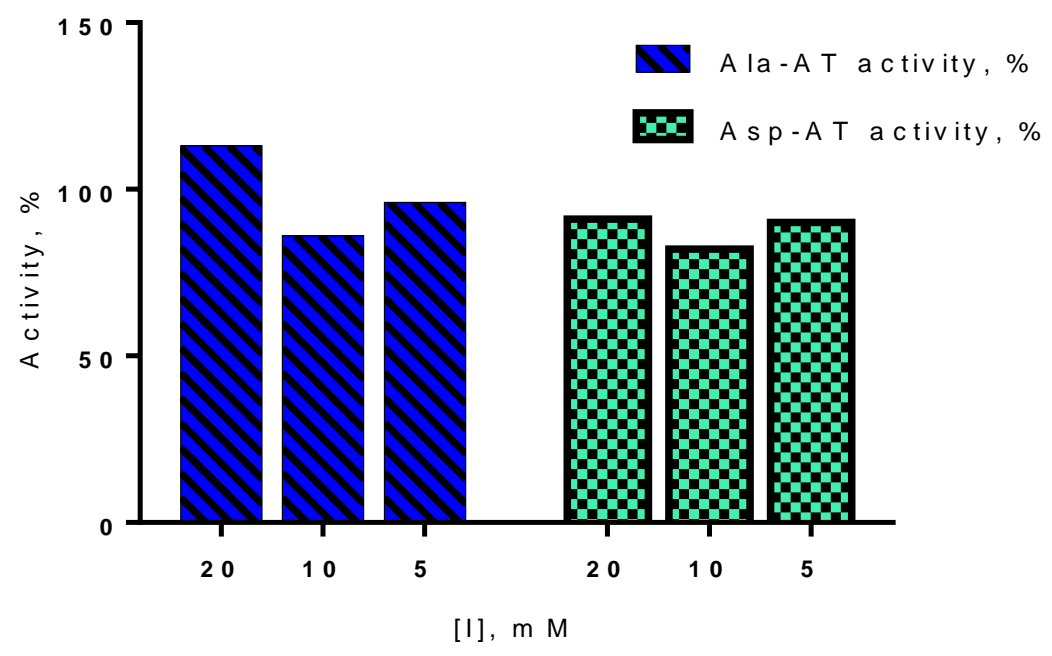

Figure S2. Inhibitory activities of 9 against different aminotransferases. (A) OAT. (B) GABA-AT. (C) Ala-AT and Asp-AT. 

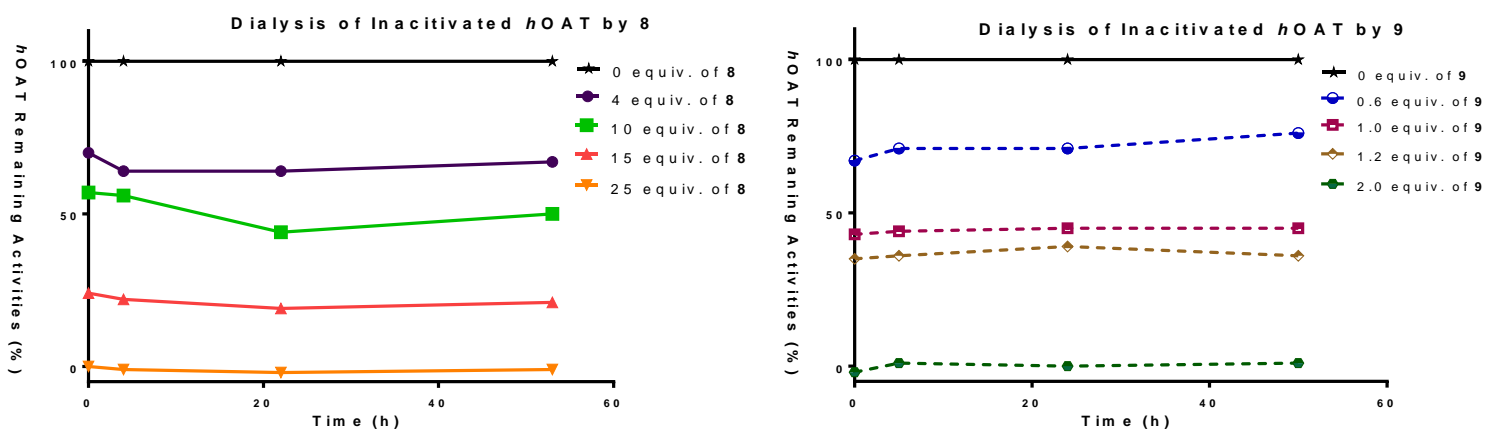

Figure S3. Time-dependent dialysis of partially or fully inhibited $h \mathrm{OAT}$ by varying concentrations of $\mathbf{8}$ (left) and $\mathbf{9}$ (right).
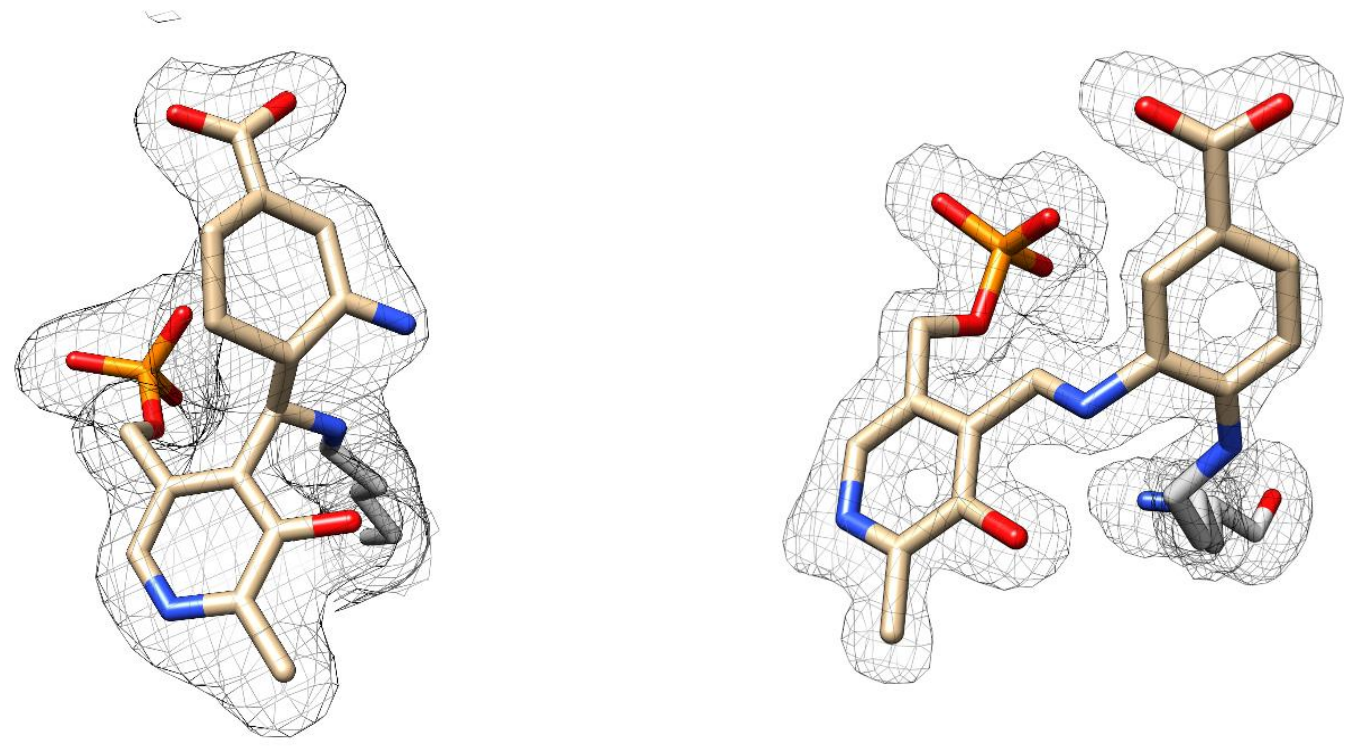

Figure S4. A polder map $\left(\mathrm{F}_{\mathrm{o}}-\mathrm{F}_{\mathrm{c}}\right.$ at $\left.3.0 \sigma\right)$ generated by omitting 16a, PLP, and Lys292 was superimposed with the ternary adduct (left). A polder map $\left(\mathrm{F}_{\mathrm{o}}-\mathrm{F}_{\mathrm{c}}\right.$ at $\left.2.5 \sigma\right)$ generated by omitting 26, PLP, and Lys292 was superimposed with the ternary adduct (right). 


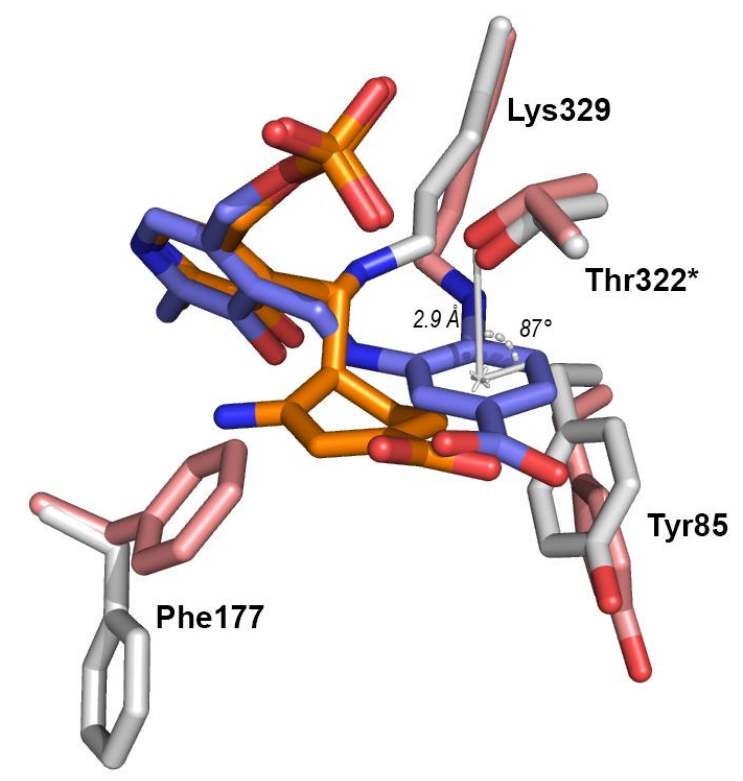

Figure S5. Active sites comparison of inactivated $h \mathrm{OAT}-\mathbf{8}$ (protein in gray, adduct in orange) and hOAT-9 (protein in pink, adduct in blue).
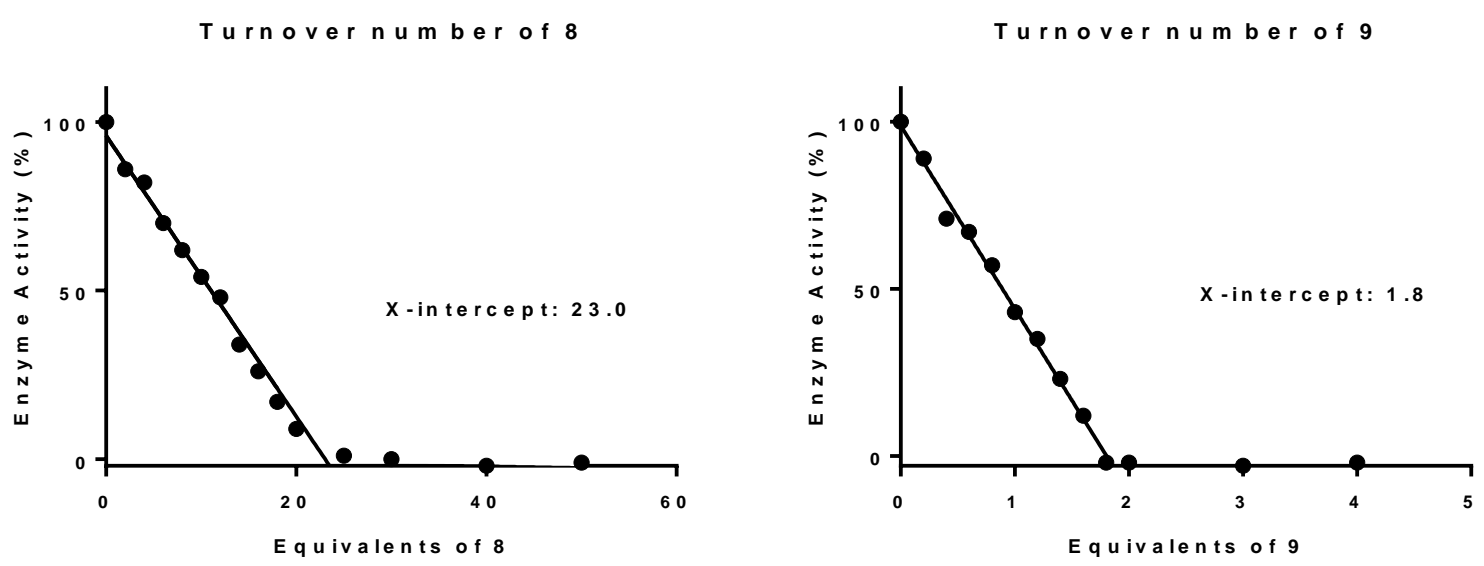

Figure S6. Titration of an enzyme with a mechanism-based enzyme inactivator. The loss of enzyme activity is measured as a function of the ratio of inactivation to enzyme concentration. Linear regression was used on the linear portion of the curves to obtain the X-intercept, which is the turnover number (partition ratio = turnover number -1 ). Determination of the turnover number for 8 (Left). Determination of the turnover number for 9 (Right). 
A)

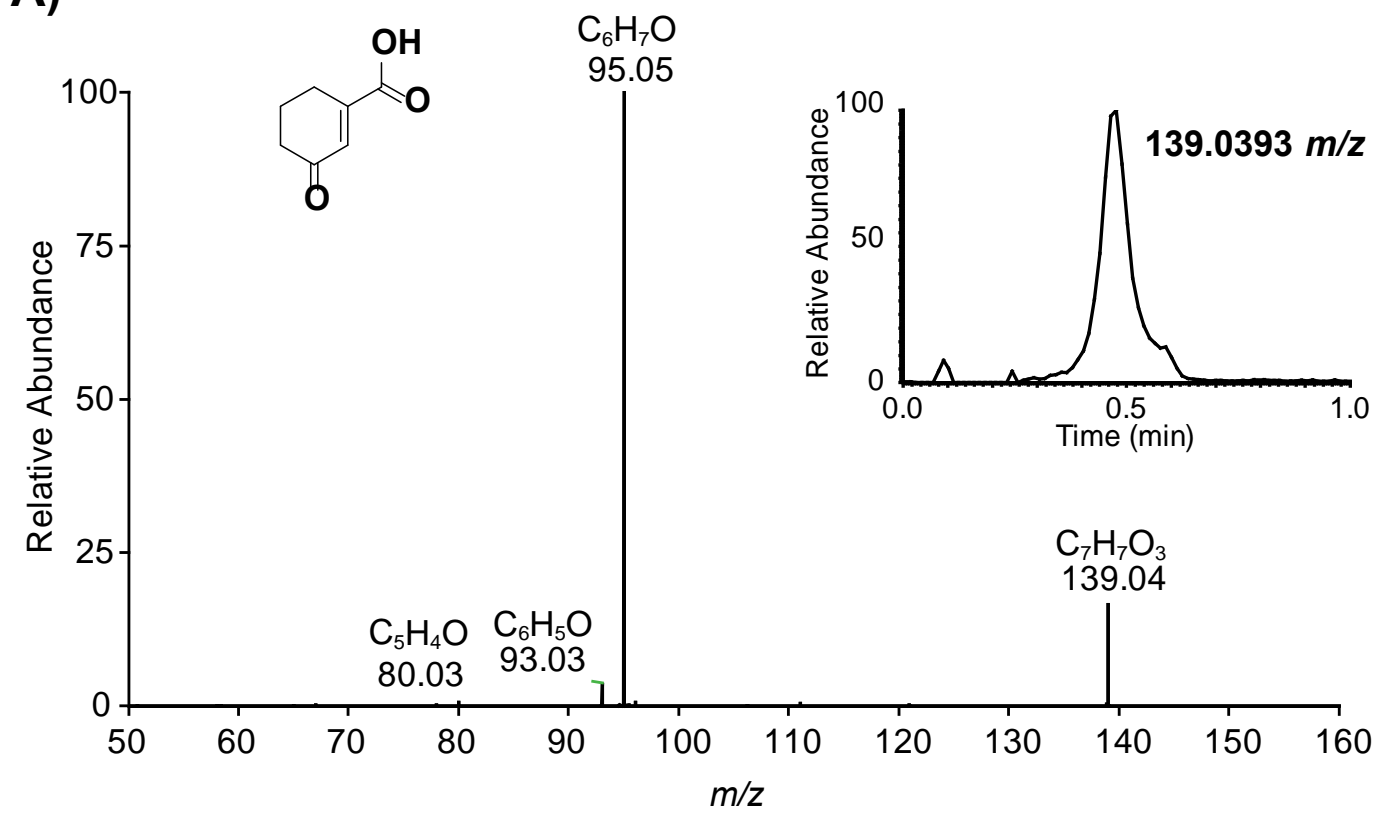

B)

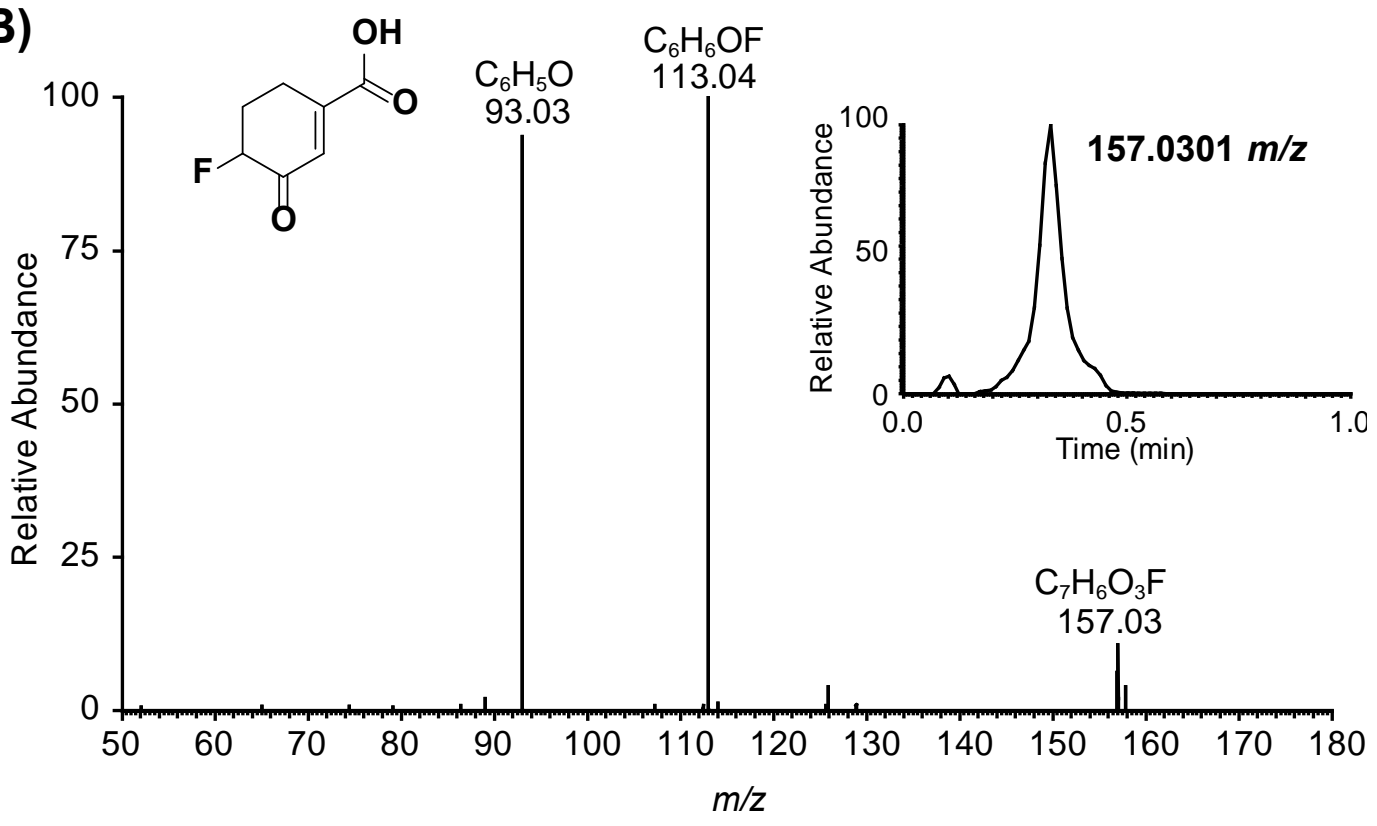

Figure S7. (A) MS2 for 39a; (B) MS2 for 39b. Treated $h \mathrm{OAT}$ was subjected to untargeted (-) ESI HRMS on an Orbitrap Q-Exactive mass spectrometer. HCD fragmentation (NCE 30) was performed to generate high resolution MS/MS confirmation of A) 39a $(139.0393 \mathrm{~m} / \mathrm{z}$ precursor chromatogram inset) and B) 39b (157.0301 $\mathrm{m} / \mathrm{z}$ precursor inset). 
A)
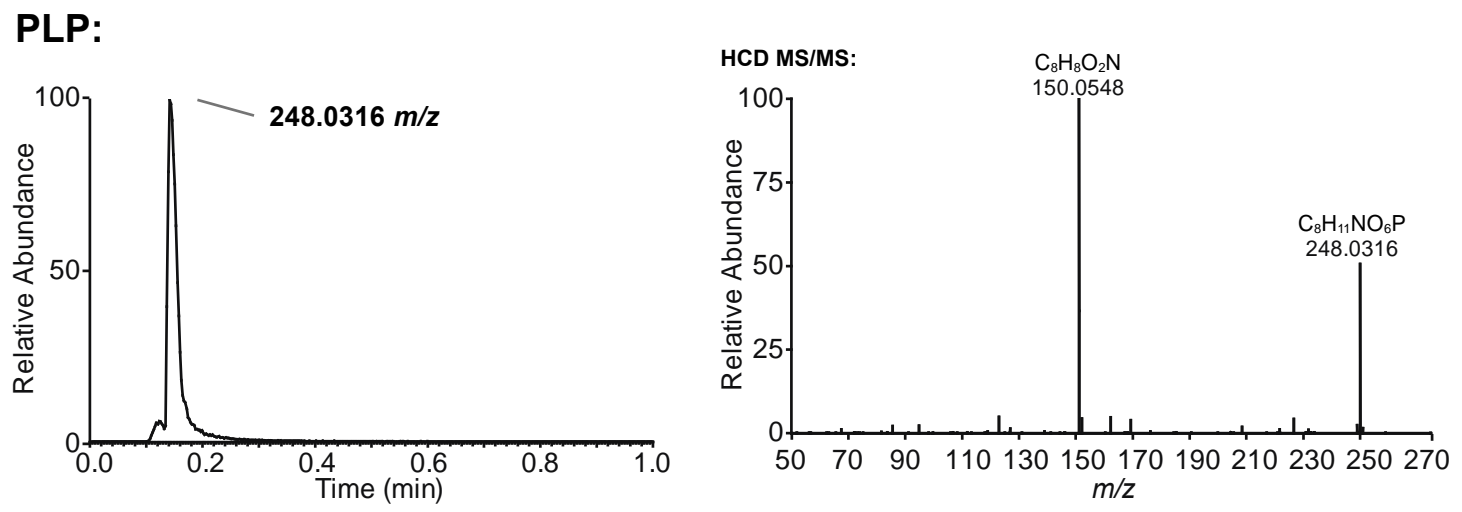

B)

PMP:
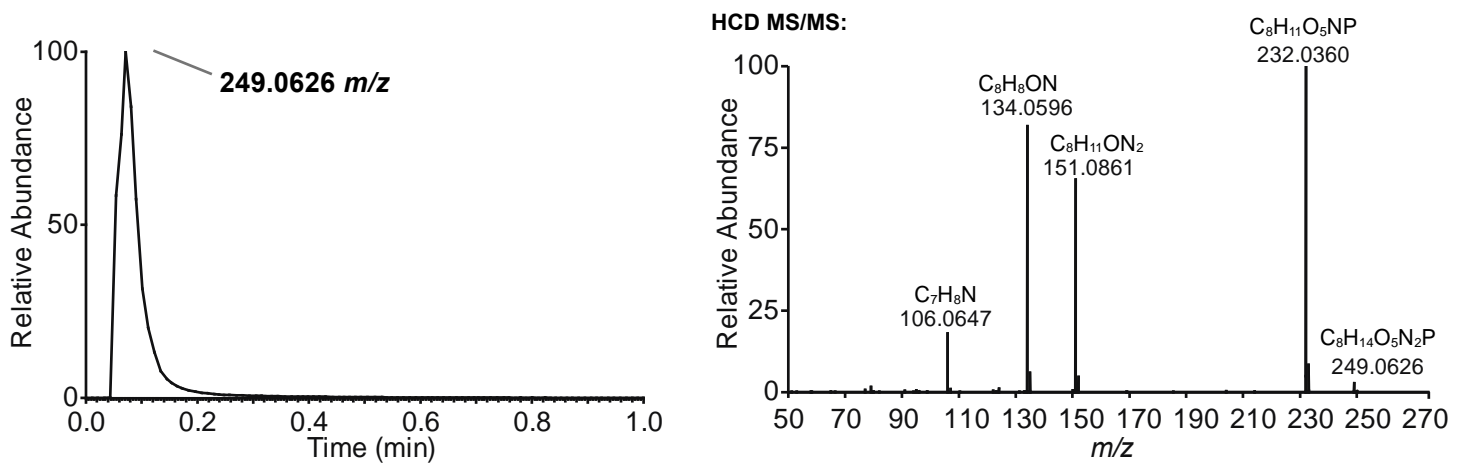

C)

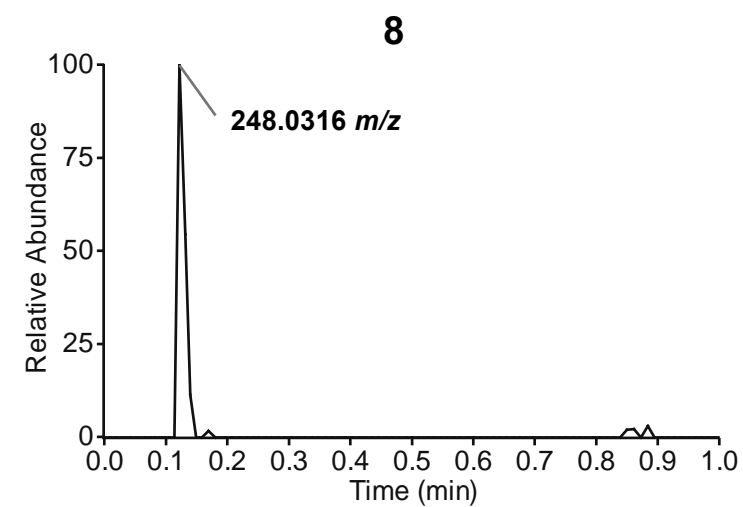

D)

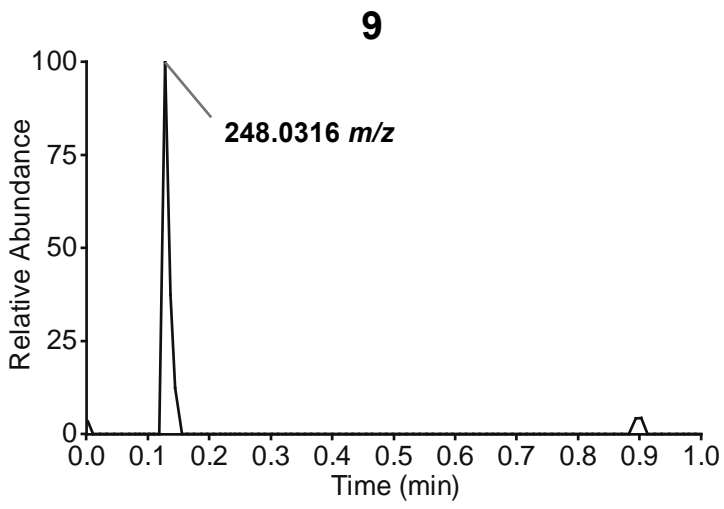

Figure S8. (A) Standard PLP spectrum. (B) Standard PMP spectrum. (C) Mass signal in 8. (D) Mass signal in 9. 
A
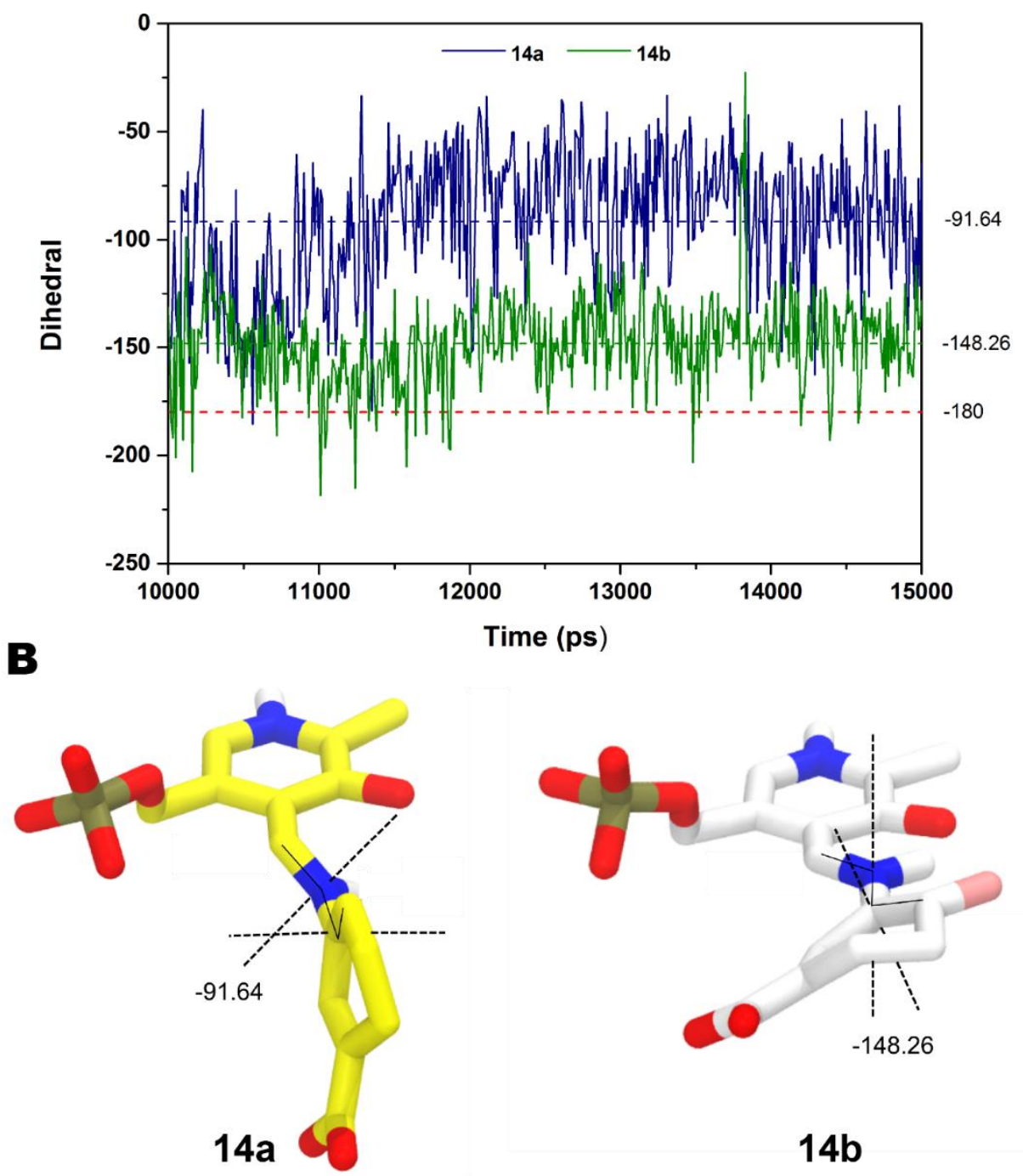

$14 b$

Figure S9. (A) Dihedral angles (between pyridine and cyclohexadiene rings) of intermediates 14a and 14b during molecular dynamics simulations. (B) The structures of intermediates 14a and 14b with the average dihedral angles shown. 

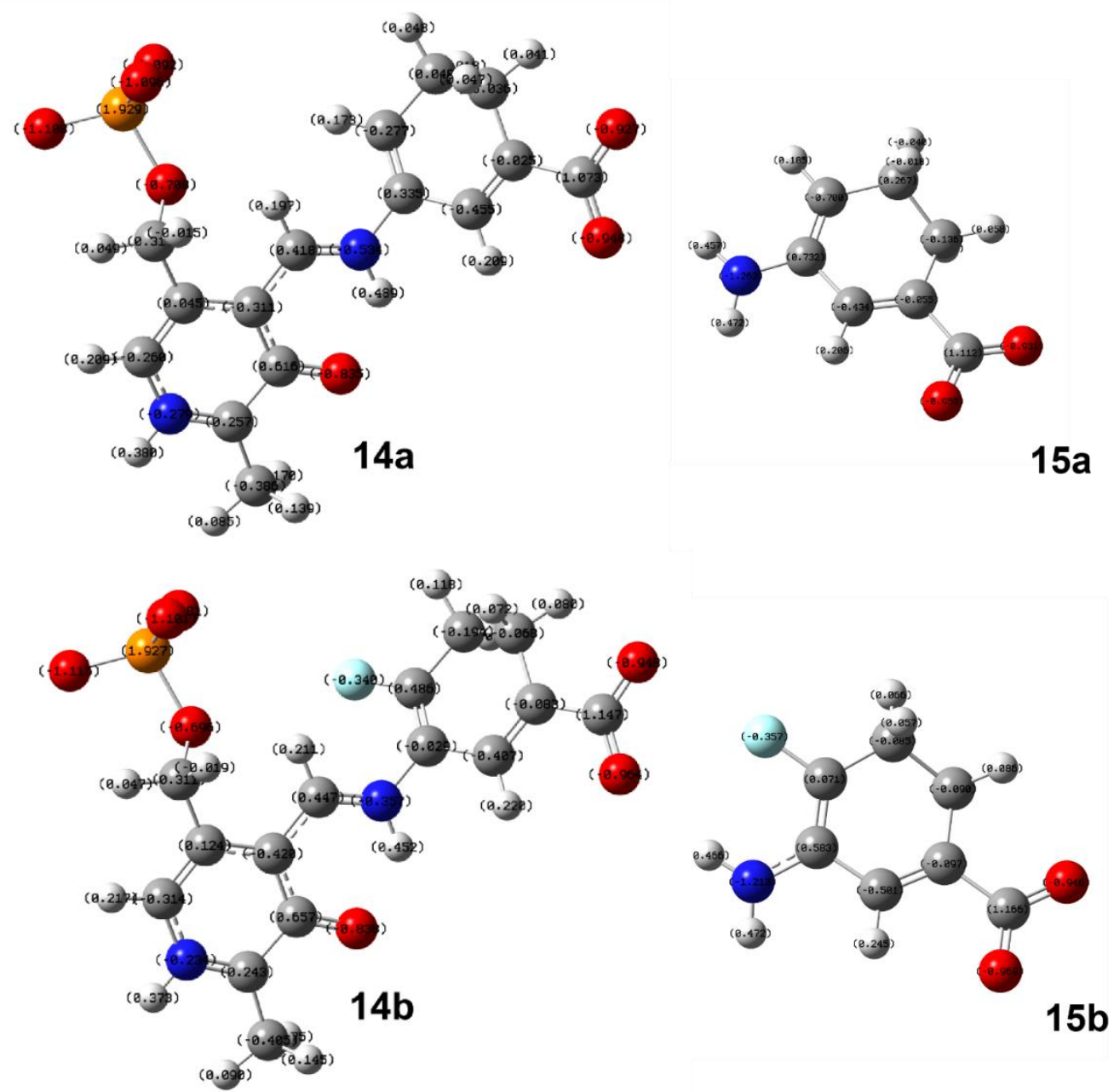

Figure S10. Calculated ESP charges for intermediates 14a, 14b, 15a and 15b. 


\section{Supplementary Tables}

Table S1. Statistics of the crystal structure of $h \mathrm{OAT}$ inactivated by $\mathbf{8}$ and $\mathbf{9}$

\begin{tabular}{|c|c|c|}
\hline $\begin{array}{l}\text { Table S1: Statistics of crystal } \\
\text { structure }\end{array}$ & hOAT-9 & $h$ OAT-8 \\
\hline \multicolumn{3}{|c|}{ Data Processing } \\
\hline Space group & $\mathrm{P} 33_{1} 12$ & C 121 \\
\hline \multicolumn{3}{|c|}{ Cell dimension } \\
\hline$\alpha, \beta, \gamma(\operatorname{deg})$ & $90,90,120$ & $90,104,90$ \\
\hline $\mathrm{a}, \mathrm{b}, \mathrm{c}(\AA)$ & 193.8193 .857 .2 & 202.8. 112.1, 57.9 \\
\hline Processed Resolution $(\AA)$ & 1.90 & 2.20 \\
\hline Resolution at $\mathrm{I} / \sigma(\mathrm{I})=2^{\mathrm{a}}$ & 1.90 & 2.20 \\
\hline $\mathrm{R}_{\text {merge }}{ }^{\mathrm{b}}(\%)$ & $8.3(36.5)^{\mathrm{c}}$ & $7.0(19.7)$ \\
\hline $\mathrm{R}_{\text {pim }}{ }^{\mathrm{d}}(\%)$ & $2.0(9.9)$ & $4.6(14.0)$ \\
\hline $\mathrm{I} / \sigma(\mathrm{I})$ & $54.3(7.7)$ & $15.0(6.9)$ \\
\hline $\mathrm{CC}^{1 / 2}{ }^{\mathrm{e}}(\%)$ & $(98.9)$ & $(99.7)$ \\
\hline Completeness $(\%)$ & $83.5(98.1)$ & $90.4(52.7)$ \\
\hline Multiplicity & 18.4 & 6.9 \\
\hline No. Reflections & 1725260 & 396889 \\
\hline No. Unique Reflections & 94007 & 57505 \\
\hline \multicolumn{3}{|c|}{ Refinement } \\
\hline $\mathrm{R}_{\text {work }}{ }^{\mathrm{f}} / \mathrm{R}_{\text {free }}{ }^{\mathrm{g}}(\%)$ & $23.45 / 26.70$ & $15.92 / 19.89$ \\
\hline \multicolumn{3}{|c|}{ No. of Atoms } \\
\hline protein & 9475 & 9480 \\
\hline ligand & 75 & 78 \\
\hline water & 843 & 403 \\
\hline \multicolumn{3}{|c|}{ B factors $\left(\AA^{2}\right)$} \\
\hline protein & 24.2 & 25.6 \\
\hline \multicolumn{3}{|c|}{ RMSD $^{\mathrm{h}}$} \\
\hline bond lengths $(\AA)$ & 0.007 & 0.009 \\
\hline
\end{tabular}




\begin{tabular}{|c|c|c|}
\hline bond angles (deg) & 0.812 & 1.562 \\
\hline & Ramachandran plot (\%) \\
\hline most favored & 95.36 & 95.27 \\
\hline allowed & 4.15 & 4.06 \\
\hline outliers & 0.50 & 0.60 \\
\hline
\end{tabular}

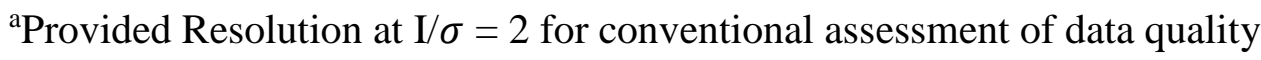

${ }^{\mathrm{b}} \mathrm{R}_{\text {merge }}=\Sigma \mid$ Iobs - Iavg $\mid / \Sigma$ Iavg

${ }^{\mathrm{c}}$ The values for the highest-resolution bin are in parentheses

${ }^{\mathrm{d}}$ Precision-indicating merging $\mathrm{R}$

ePearson correlation coefficient of two "half" data sets

${ }^{\mathrm{f}} \mathrm{R}_{\text {work }}=\Sigma \mid$ Fobs - Fcalc $\mid / \Sigma$ Fobs

${ }^{\mathrm{g}}$ Five percent of the reflection data were selected at random as a test set, and only these data were used to calculate $\mathrm{R}_{\text {free }}$

${ }^{\text {h}}$ Root-mean square deviation 
Table S2. Calculation of fluoride ion release for $\mathbf{8}$ and $\mathbf{9}$

\begin{tabular}{|c|c|c|c|c|c|c|}
\hline Compound 8 & $\begin{array}{l}\text { Control } \\
\text { Trial } 1\end{array}$ & $\begin{array}{l}\text { Control } \\
\text { Trial } 2\end{array}$ & $\begin{array}{c}\text { Control } \\
\text { Trial } 3\end{array}$ & $\begin{array}{l}\text { Sample } \\
\text { Trial } 1\end{array}$ & $\begin{array}{c}\text { Sample } \\
\text { Trial } 2\end{array}$ & $\begin{array}{c}\text { Sample } \\
\text { Trial } 3\end{array}$ \\
\hline Test-1 (mV) & 163.6 & 163.3 & 165.8 & 127.8 & 127.8 & 127.2 \\
\hline Test-2 (mV) & 163.5 & 163.6 & 165.7 & 127.6 & 127.6 & 127.4 \\
\hline Test-3 (mV) & 163.8 & 163.5 & 165.5 & 127.1 & 127.4 & 127.6 \\
\hline $\operatorname{Ave}(\mathbf{m V})$ & 163.63 & 163.47 & 165.67 & 127.5 & 127.6 & 127.4 \\
\hline $\mathbf{F}^{-}$Detected $(\boldsymbol{\mu M})$ & 2.21 & 2.22 & 2.02 & 10.54 & 10.50 & 10.59 \\
\hline $\mathrm{F}^{-}$Detected Ave $(\mu \mathrm{M})$ & \multicolumn{3}{|c|}{ Control: $2.15 \pm 0.092$} & \multicolumn{3}{|c|}{ Sample: $10.54 \pm 0.037$} \\
\hline $\mathbf{F}^{-}$Release $(\boldsymbol{\mu M})$ & \multicolumn{6}{|c|}{8.39} \\
\hline Enzyme Concentration & \multicolumn{6}{|c|}{$0.37 \pm 0.01 \mu \mathrm{M}$ (Monomer) } \\
\hline \multicolumn{4}{|c|}{ Fluoride ions released per active site (8) } & \multicolumn{3}{|c|}{22.7 equiv } \\
\hline Compound 9 & $\begin{array}{l}\text { Control } \\
\text { Trial } 1\end{array}$ & $\begin{array}{c}\text { Control } \\
\text { Trial } 2\end{array}$ & $\begin{array}{l}\text { Control } \\
\text { Trial } 3\end{array}$ & $\begin{array}{c}\text { Sample } \\
\text { Trial } 1\end{array}$ & $\begin{array}{c}\text { Sample } \\
\text { Trial } 2\end{array}$ & $\begin{array}{c}\text { Sample } \\
\text { Trial } 3\end{array}$ \\
\hline Test-1 (mV) & 164.0 & 163.2 & 165.4 & 155.5 & 155 & 155.4 \\
\hline Test-2 (mV) & 164.2 & 163.1 & 165 & 155.0 & 154.8 & 155.0 \\
\hline Test-3 (mV) & 164.4 & 162.6 & 165.2 & 154.8 & 154.5 & 155.1 \\
\hline $\operatorname{Ave}(\mathbf{m V})$ & 164.2 & 162.97 & 165.2 & 155.1 & 154.77 & 155.17 \\
\hline $\mathbf{F}^{-}$Detected $(\boldsymbol{\mu M})$ & 2.15 & 2.27 & 2.06 & 3.19 & 3.28 & 3.18 \\
\hline F- Detected Ave $(\mu M)^{-}$ & \multicolumn{3}{|c|}{ Control: $2.16 \pm 0.086$} & \multicolumn{3}{|c|}{ Sample: $3.22 \pm 0.045$} \\
\hline $\mathrm{F}^{-}$Release $(\mu \mathrm{M})$ & \multicolumn{6}{|c|}{1.06} \\
\hline Enzyme Concentration & \multicolumn{6}{|c|}{$0.37 \pm 0.01 \mu \mathrm{M}$ (Monomer) } \\
\hline \multicolumn{4}{|c|}{ Fluoride ions released per active site (9) } & \multicolumn{3}{|c|}{2.9 equiv } \\
\hline
\end{tabular}




\section{Synthesis of Inactivators 8-11}

\section{General Synthetic Methods}

All chemicals were purchased from Sigma Aldrich, Acros Organics, or Combi-block and used without further purification. Anhydrous solvents (THF) were purified before use by passing through a column composed of activated alumina and a supported copper redox catalyst. Yields refer to chromatographically homogeneous materials. Analytical thin-layer chromatography (TLC) was performed using Merck Silica Gel 60 Å F-254 precoated plates (0.25 mm thickness), and components were visualized by ultraviolet light $(254 \mathrm{~nm})$ and/or ceric ammonium molybdate stain and/or ninhydrin stain. Flash column chromatography was performed on a Teledyne Combiflash Rf Plus automated flash purification system with various Taledyne cartridges (4-80 g, 40-63 $\mu \mathrm{m}$, $60 \AA$ A). Purifications were performed with hexanes and ethyl acetate unless otherwise noted. ${ }^{1} \mathrm{H}$ and ${ }^{13} \mathrm{C}$ NMR spectra were recorded on a Bruker Avance-III NMR spectrometer at $500 \mathrm{MHz}$ and $126 \mathrm{MHz}$, respectively, in $\mathrm{CDCl}_{3}, \mathrm{CD}_{3} \mathrm{OD}$ or DMSO- $d_{6}$. Chemical shifts were reported in ppm; multiplicities are indicated by $\mathrm{s}=$ singlet, $\mathrm{d}=$ doublet, $\mathrm{t}=$ triplet, $\mathrm{q}=$ quartet, $\mathrm{dd}=$ doublet of doublet, $\mathrm{dt}=$ doublet of triplet, $\mathrm{dq}=$ doublet of quartet, $\mathrm{m}=$ multiplet resonance. Coupling constants ' $\mathrm{J}$ ' were reported in Hz. High-resolution mass spectral data were obtained on an Agilent 6210 LC-TOF spectrometer in the positive ion mode using electrospray ionization with an Agilent G1312A HPLC pump and an Agilent G1367B autoinjector at the Integrated Molecular Structure Education and Research Center (IMSERC), Northwestern University. Analytical HPLC was performed using a reversed-phase Agilent Infinity 1260 HPLC with a Phenomenex Kintex C-18 column $(50 \times 2.1 \mathrm{~mm}, 2.6 \mu \mathrm{m})$, detecting with UV absorbance at $254 \mathrm{~nm}$.

$(1 R, 4 R, 5 R)-4-I o d o-6-o x a b i c y c l o[3.2 .1]$ octan-7-one (28). To a stirred solution of $\mathrm{NaHCO}_{3}$ (15.98 g, $190.74 \mathrm{mmol}, 3.0$ equiv) in water (200 mL) was added $(R)$-cyclohex-3-ene-1-carboxylic acid 27 ( 8 g, $63.41 \mathrm{mmol}, 1.0$ equiv) slowly in an ice bath. KI (52.36 g, 317.07 mmol, 5.0 equiv) and $\mathrm{I}_{2}(17.7 \mathrm{~g}, 69.76 \mathrm{mmol}, 1.1$ equiv) were added portionwise. The ice bath was removed after $30 \mathrm{~min}$ and stirred at r.t. overnight. The reaction was quenched with sat. $\mathrm{Na}_{2} \mathrm{~S}_{2} \mathrm{O}_{3}$ (aq. $150 \mathrm{~mL}$ ) and extracted with EtOAc $(200 \mathrm{~mL})$ three times. The combined organic phase was washed with brine $(10 \mathrm{~mL})$ and dried with anhydrous $\mathrm{Na}_{2} \mathrm{SO}_{4}$. The solution was concentrated to give a brown solid, which was dispensed in hexane $(100 \mathrm{~mL})$ and stirred for $3 \mathrm{~h}$. The suspension was filtered to give a pale brown powder $(\mathbf{2 9}, 15.2 \mathrm{~g}, 95 \%) .{ }^{1} \mathrm{H} \mathrm{NMR}\left(500 \mathrm{MHz}, \mathrm{CDCl}_{3}\right) \delta 4.82(\mathrm{dd}, J=5.9,4.2$ 
$\mathrm{Hz}, 1 \mathrm{H}), 4.50(\mathrm{t}, J=5.0 \mathrm{~Hz}, 1 \mathrm{H}), 2.79(\mathrm{~d}, J=12.3 \mathrm{~Hz}, 1 \mathrm{H}), 2.67(\mathrm{~s}, 1 \mathrm{H}), 2.48-2.35(\mathrm{~m}, 2 \mathrm{H}), 2.11$ $(\mathrm{dd}, J=16.5,5.3 \mathrm{~Hz}, 1 \mathrm{H}), 1.90(\mathrm{tdd}, J=13.0,5.4,2.1 \mathrm{~Hz}, 1 \mathrm{H}), 1.82(\mathrm{dt}, J=12.8,5.4 \mathrm{~Hz}, 1 \mathrm{H}) .{ }^{13} \mathrm{C}$ NMR $\left(126 \mathrm{MHz} \mathrm{CDCl}_{3}\right) \delta 177.9,80.4,38.7,34.6,29.9,23.9,23.3$. LRMS (APCI) $\left(\mathrm{M}+\mathrm{H}^{+}\right)$: 252.85 .

\section{Ethyl (1R,3S,4S)-3-(bis(4-methoxybenzyl)amino)-4-hydroxycyclohexane-1-carboxylate (29).} A suspension of 28 (28.7 g, $118.9 \mathrm{mmol}, 1.0$ equiv) in $\mathrm{EtOH}(100 \mathrm{~mL})$ was stirred in an ice bath. A solution of $\mathrm{NaOH}(2 \mathrm{M}, 65 \mathrm{~mL}, 130.8 \mathrm{mmol}, 1.1$ equiv) was added dropwise. The ice bath was removed after the addition, and the solution was stirred at r.t. for $4 \mathrm{~h}$. The solution was concentrated below $40{ }^{\circ} \mathrm{C}$, diluted with water $(100 \mathrm{~mL})$, and extracted with DCM $(200 \mathrm{~mL}) 3$ times. The combined organic phase was washed with water $(100 \mathrm{~mL})$ and brine $(100 \mathrm{~mL})$ and dried with anhydrous $\mathrm{Na}_{2} \mathrm{SO}_{4}$. The solution was concentrated to give a brown oil (15.3 g). To a solution of the obtained brown oil $(10.5 \mathrm{~g})$ in $\mathrm{EtOH}(50 \mathrm{~mL})$ was added aqueous ammonia $(28-30 \%, 100 \mathrm{~mL})$. The solution was heated to $45^{\circ} \mathrm{C}$ and stirred overnight. The completion of reaction was determined by LC-MS. The solution was concentrated to give the crude amino alcohol intermediate (11.1g). To a solution of the crude intermediate $(6.0 \mathrm{~g}, 32.04 \mathrm{mmol}, 1.0$ equiv) in DCE (200 mL) was added 4-anisaldehyde (13.1 g, 96.13 mmol, 3.0 equiv) and $\mathrm{AcOH}$ (5.77 g, $96.13 \mathrm{mmol}, 3.0$ equiv). The solution was heated to $75^{\circ} \mathrm{C}$ and stirred for $1 \mathrm{~h}$. To this solution was added $\mathrm{NaBH}(\mathrm{OAc})_{3}(20.37$ $\mathrm{g}, 96.13 \mathrm{mmol}, 3.0$ equiv) protionwise over $2 \mathrm{~h}$. The resulting mixture was stirred at $75{ }^{\circ} \mathrm{C}$ overnight. The completion of the reaction was determined by LC-MS. The mixture was cooled to r.t. and diluted with DCM (200 mL) and water (200 mL). After being stirred for $10 \mathrm{~min}$, the organic phase was separated and then washed sequentially with water (200 mL), $\mathrm{NaHCO}_{3}$ (aq. $200 \mathrm{~mL}$ ), and brine $(100 \mathrm{~mL})$. The organic phase was dried with anhydrous $\mathrm{Na}_{2} \mathrm{SO}_{4}$. The solution was concentrated and purified by silica gel chromatography (50\% EtOAc in hexane) to afford a white solid (29, $6.297 \mathrm{~g}, 35 \%$ for three steps). ${ }^{1} \mathrm{H} \mathrm{NMR}\left(500 \mathrm{MHz}, \mathrm{CDCl}_{3}\right) \delta 7.17(\mathrm{~d}, J=8.5 \mathrm{~Hz}, 4 \mathrm{H})$, $6.84(\mathrm{~d}, J=8.6 \mathrm{~Hz}, 4 \mathrm{H}), 4.17(\mathrm{dq}, J=10.8,7.1 \mathrm{~Hz}, 1 \mathrm{H}), 4.07(\mathrm{dq}, J=10.8,7.1 \mathrm{~Hz}, 1 \mathrm{H}), 3.79$ (s, $1 \mathrm{H}), 3.78(\mathrm{~s}, 6 \mathrm{H}), 3.74(\mathrm{~d}, J=13.1 \mathrm{~Hz}, 2 \mathrm{H}), 3.63(\mathrm{~s}, 1 \mathrm{H}), 3.47$ (td, $J=10.4,4.5 \mathrm{~Hz}, 1 \mathrm{H}), 3.31$ (d, $J=13.0 \mathrm{~Hz}, 2 \mathrm{H}), 2.80(\mathrm{dp}, J=4.9,2.2 \mathrm{~Hz}, 1 \mathrm{H}), 2.53(\mathrm{ddd}, J=12.7,9.8,3.4 \mathrm{~Hz}, 1 \mathrm{H}), 2.47(\mathrm{dq}, J$ $=12.9,2.7 \mathrm{~Hz}, 1 \mathrm{H}), 2.17(\mathrm{dp}, J=14.0,3.1 \mathrm{~Hz}, 1 \mathrm{H}), 1.97(\mathrm{dq}, J=11.6,3.4 \mathrm{~Hz}, 1 \mathrm{H}), 1.50-1.42$ $(\mathrm{m}, 2 \mathrm{H}), 1.23(\mathrm{t}, J=7.1 \mathrm{~Hz}, 3 \mathrm{H}) .{ }^{13} \mathrm{C} \mathrm{NMR}\left(126 \mathrm{MHz}, \mathrm{CDCl}_{3}\right) \delta 174.1,158.8,131.5,130.3,113.9$, $68.7,60.7,60.3,55.3,52.6,39.6,30.1,25.1,23.5,14.4$. HRMS (ESI) calc'd for $\mathrm{C}_{25} \mathrm{H}_{34} \mathrm{NO}_{5}$ $\left(\mathrm{M}+\mathrm{H}^{+}\right)$: 428.2431, found: 428.242. 
Ethyl (1R,3S,4S)-3-(bis(4-methoxybenzyl)amino)-4-fluorocyclohexane-1-carboxylate (30). To a stirred suspension of XtalFluor-M (7.67 g, $31.65 \mathrm{mmol}, 1.5$ equiv) in DCM (100 mL) in a plastic container was slowly added a solution of $29\left(9.0 \mathrm{~g}, 21.05 \mathrm{mmol}, 1.0\right.$ equiv) and $(\mathrm{HF})_{3} \mathrm{Et}_{3} \mathrm{~N}$ (5.09 $\mathrm{g}, 31.65 \mathrm{mmol}, 1.5$ equiv) in DCM (50 mL) under Ar. After the addition was completed, the mixture was stirred at r.t. overnight. The completion of the reaction was determined by TLC (hexane: EtOAc $=2: 1)$. The reaction was diluted with DCM $(100 \mathrm{~mL})$ and quenched with water $(50 \mathrm{~mL})$. The organic phase was separated and then washed sequentially with water $(100 \mathrm{~mL})$, $\mathrm{NaHCO}_{3}$ (aq. $100 \mathrm{~mL}$ ), and brine $(100 \mathrm{~mL})$. The organic phase was dried with anhydrous $\mathrm{Na}_{2} \mathrm{SO}_{4}$. The solution was concentrated and purified by silica gel chromatography (25\% EtOAc in hexane) to afford a colorless oil (30, $6.81 \mathrm{~g}, 75 \%) .{ }^{1} \mathrm{H} \mathrm{NMR}\left(500 \mathrm{MHz}, \mathrm{CDCl}_{3}\right) \delta 7.30(\mathrm{~d}, J=8.5 \mathrm{~Hz}, 4 \mathrm{H})$, $6.84(\mathrm{~d}, J=8.6 \mathrm{~Hz}, 4 \mathrm{H}), 4.62(\mathrm{dtd}, J=50.5,10.3,4.8 \mathrm{~Hz}, 1 \mathrm{H}), 4.01(\mathrm{dq}, J=10.8,7.1 \mathrm{~Hz}, 1 \mathrm{H})$, $3.91(\mathrm{dq}, J=10.8,7.1 \mathrm{~Hz}, 1 \mathrm{H}), 3.78(\mathrm{~s}, 6 \mathrm{H}), 3.73(\mathrm{~d}, J=13.6 \mathrm{~Hz}, 2 \mathrm{H}), 3.65$ (d, $J=13.5 \mathrm{~Hz}, 2 \mathrm{H})$, 2.85 (dddd, $J=12.3,9.7,8.4,3.9 \mathrm{~Hz}, 1 \mathrm{H}), 2.66$ (dh, $J=5.5,2.8 \mathrm{~Hz}, 1 \mathrm{H}$ ), 2.32 (ddq, $J=12.8,6.2$, $3.0 \mathrm{~Hz}, 1 \mathrm{H}), 2.19-2.10(\mathrm{~m}, 1 \mathrm{H}), 2.03(\mathrm{ddq}, J=12.3,8.2,4.1 \mathrm{~Hz}, 1 \mathrm{H}), 1.64-1.47$ (m, 2H), 1.38 (tddd, $J=13.7,5.1,3.6,1.4 \mathrm{~Hz}, 1 \mathrm{H}), 1.08(\mathrm{t}, J=7.1 \mathrm{~Hz}, 3 \mathrm{H}) .{ }^{13} \mathrm{C} \mathrm{NMR}\left(126 \mathrm{MHz}, \mathrm{CDCl}_{3}\right) \delta$ $173.9,158.6,132.5$, $129.8,113.6,92.5(\mathrm{~d}, J=178.1 \mathrm{~Hz}), 60.6,57.8(\mathrm{~d}, J=16.1 \mathrm{~Hz}), 55.3$, $53.6,39.0(\mathrm{~d}, J=2.0 \mathrm{~Hz}), 29.2(\mathrm{~d}, J=18.7 \mathrm{~Hz}), 28.6(\mathrm{~d}, J=8.4 \mathrm{~Hz}), 24.9$ (d, $J=11.2 \mathrm{~Hz}), 14.1$. HRMS (ESI) calc'd for $\mathrm{C}_{25} \mathrm{H}_{33} \mathrm{FNO}_{4}\left(\mathrm{M}+\mathrm{H}^{+}\right)$: 430.2388, found: 430.238.

Ethyl (1R,3S,4S)-3-((tert-butoxycarbonyl)amino)-4-fluorocyclohexane-1-carboxylate (31). To a solution of 30 (5.0 g, $17.46 \mathrm{mmol}, 1.0$ equiv) in $\mathrm{MeOH}(50 \mathrm{~mL})$ and EtOAc $(50 \mathrm{~mL})$ was added $\mathrm{Boc}_{2} \mathrm{O}$ (3.81 g, $11.64 \mathrm{mmol}, 1.0$ equiv) and $\mathrm{Pd}(\mathrm{OH})_{2}(1.0 \mathrm{~g}, 20 \% \mathrm{wt})$ under Ar. The flask was evacuated to remove the Ar and then refilled with a $\mathrm{H}_{2}$ balloon. The mixture was stirred at r.t. overnight. The completion of the reaction was determined by LC-MS. The suspension was filtered through a Celite pad and washed with an additional $100 \mathrm{~mL}$ of EtOAc. The filtrate was concentrated and purified by silica gel chromatography (20\% EtOAc in hexane) to afford a white solid (31, $2.73 \mathrm{~g}, 81 \%)$. ${ }^{1} \mathrm{H}$ NMR (500 MHz, $\left.\mathrm{CDCl}_{3}\right) \delta 4.55(\mathrm{~s}, 1 \mathrm{H}), 4.47$ (d, $\left.J=39.7 \mathrm{~Hz}, 1 \mathrm{H}\right)$, 4.15 (q, $J=7.1 \mathrm{~Hz}, 2 \mathrm{H}), 3.89$ (s, 1H), 2.49 (s, 1H), 2.23 (ddt, $J=13.3,8.5,4.1 \mathrm{~Hz}, 1 \mathrm{H}), 2.00$ $1.76(\mathrm{~m}, 3 \mathrm{H}), 1.76-1.64(\mathrm{~m}, 2 \mathrm{H}), 1.44(\mathrm{~s}, 10 \mathrm{H}), 1.26(\mathrm{t}, J=7.1 \mathrm{~Hz}, 3 \mathrm{H}) .{ }^{13} \mathrm{C} \mathrm{NMR}(126 \mathrm{MHz}$, $\left.\mathrm{CDCl}_{3}\right) \delta 174.3,155.2,90.589 .8(\mathrm{~d}, J=173.2 \mathrm{~Hz}), 60.8,49.3,38.0,29.8,26.7(\mathrm{~d}, J=20.2 \mathrm{~Hz})$, $23.4(\mathrm{~d}, J=5.4 \mathrm{~Hz}), 14.4 .{ }^{19} \mathrm{~F}$ NMR $\left(564 \mathrm{MHz}, \mathrm{CD}_{3} \mathrm{OD}\right) \delta-181.34(\mathrm{~d}, J=50.7 \mathrm{~Hz}) . \mathrm{HRMS}(\mathrm{ESI})$ calc'd for $\mathrm{C}_{14} \mathrm{H}_{24} \mathrm{FNNaO}_{4}\left(\mathrm{M}+\mathrm{Na}^{+}\right)$: 312.158 , found: 312.1582 . 
Ethyl (4S,5S)-5-((tert-butoxycarbonyl)amino)-4-fluorocyclohex-1-ene-1-carboxylate (32b) \& ethyl (3S,4S)-3-((tert-butoxycarbonyl)amino)-4-fluorocyclohex-1-ene-1-carboxylate (32a). To a stirred solution of KHMDS (1M in THF, $10.89 \mathrm{~mL}, 10.89 \mathrm{mmol}, 2.1$ equiv) was slowly added dry THF (10 mL), and a solution of $\mathbf{3 1}$ (1.5 g, $5.18 \mathrm{mmol}, 1.0$ equiv) in dry THF (30 mL) was added at $-78{ }^{\circ} \mathrm{C}$ under Ar over $30 \mathrm{~min}$. The solution was stirred at $-78{ }^{\circ} \mathrm{C}$ for an additional $3 \mathrm{~h}$, followed by the addition of a solution of $\mathrm{PhSeCl}(1.09 \mathrm{mg}, 5.70 \mathrm{mmol}, 1.1$ equiv) in THF (10 mL). The solution was then slowly warmed to r.t. and stirred overnight. The reaction was quenched with the addition of sat. $\mathrm{NH}_{4} \mathrm{Cl}(20 \mathrm{~mL})$. The solution was then diluted with EtOAc $(200 \mathrm{~mL})$, and the organic phase was separated. The aqueous phase was extracted with EtOAc (100 mL) twice. The combined organic layers were washed with brine $(c a .30 \mathrm{~mL})$ and dried with anhydrous $\mathrm{Na}_{2} \mathrm{SO}_{4}$. The solution was concentrated and gave a yellow oil. To a stirred solution of obtained oil (1.55 g, $3.49 \mathrm{mmol}, 1.0$ equiv) in DCM (50 mL) was added $m$-CPBA (1.17 g, $5.23 \mathrm{mmol}, 1.5$ equiv). The solution was stirred at r.t. for $3 \mathrm{~h}$. The completion of the reaction was determined by LC-MS. The reaction was quenched with $\mathrm{Na}_{2} \mathrm{~S}_{2} \mathrm{O}_{3}$ (aq. $10 \mathrm{~mL}$ ). The organic phase was separated, washed with saturated $\mathrm{NaHCO}_{3}$ (aq. $10 \mathrm{~mL}$ ) and brine $\left(10 \mathrm{~mL}\right.$ ), and dried with anhydrous $\mathrm{Na}_{2} \mathrm{SO}_{4}$. The solution was concentrated and purified by silica gel chromatography (5-10\% EtOAc in hexane) and C-18 chromatography to afford a white solid (32b, $92 \mathrm{mg}, 9 \%),{ }^{1} \mathrm{H}$ NMR $\left(500 \mathrm{MHz}, \mathrm{CDCl}_{3}\right) \delta 6.85$ (tq, $J=3.5,1.9 \mathrm{~Hz}, 1 \mathrm{H}), 4.75(\mathrm{dq}, J=47.5,4.9,4.2 \mathrm{~Hz}, 1 \mathrm{H}), 4.52(\mathrm{~s}, 1 \mathrm{H}), 4.20(\mathrm{q}, J=7.1 \mathrm{~Hz}, 2 \mathrm{H})$, $4.07(\mathrm{~s}, 1 \mathrm{H}), 2.83(\mathrm{~d}, J=17.9 \mathrm{~Hz}, 1 \mathrm{H}), 2.66(\mathrm{t}, J=23.7 \mathrm{~Hz}, 1 \mathrm{H}), 2.53(\mathrm{t}, J=19.4 \mathrm{~Hz}, 1 \mathrm{H}), 2.33$ $(\mathrm{ddq}, J=18.1,5.5,1.9 \mathrm{~Hz}, 1 \mathrm{H}), 1.44(\mathrm{~s}, 9 \mathrm{H}), 1.29(\mathrm{t}, J=7.1 \mathrm{~Hz}, 3 \mathrm{H}) .{ }^{13} \mathrm{C} \mathrm{NMR}\left(126 \mathrm{MHz}, \mathrm{CDCl}_{3}\right)$ $\delta 166.1,155.3,134.5(\mathrm{~d}, J=4.2 \mathrm{~Hz}), 128.0,87.1(\mathrm{~d}, J=176.2 \mathrm{~Hz}), 60.8,47.7,29.5(\mathrm{~d}, J=22.6$ $\mathrm{Hz}), 28.3,27.6(\mathrm{~d}, J=3.2 \mathrm{~Hz})$, 14.2. HRMS (ESI) calc'd for $\mathrm{C}_{14} \mathrm{H}_{22} \mathrm{FNNaO}_{4}\left(\mathrm{M}+\mathrm{Na}^{+}\right): 310.1425$, found: 310.1416 .

Another white solid (32a, $365 \mathrm{mg}, 36 \%)$ also was obtained. ${ }^{1} \mathrm{H}$ NMR (500 MHz, DMSO- $\left.d_{6}\right) \delta 7.27$ $(\mathrm{d}, J=8.4 \mathrm{~Hz}, 1 \mathrm{H}), 6.46$ (s, 1H), 4.60 (dddd, $J=49.1,9.3,5.9,3.1 \mathrm{~Hz}, 1 \mathrm{H}), 4.25$ (ddq, $J=14.5$, 9.0, 3.4, 2.9 Hz, 1H), 4.13 (q, J=7.1 Hz, 2H), $2.38-2.20(\mathrm{~m}, 2 \mathrm{H}), 2.05-1.94(\mathrm{~m}, 1 \mathrm{H}), 1.88$ (dp, $J=14.1,6.9 \mathrm{~Hz}, 1 \mathrm{H}), 1.40(\mathrm{~s}, 9 \mathrm{H}), 1.22(\mathrm{t}, J=7.1 \mathrm{~Hz}, 3 \mathrm{H}) \cdot{ }^{13} \mathrm{C}$ NMR $\left(126 \mathrm{MHz}, \mathrm{DMSO}-d_{6}\right) \delta$ 165.5, 155.1, 136.2, 136.2, 130.7, 90.0 (d, $J=175.2 \mathrm{~Hz}), 78.4,60.3,50.4$ (d, $J=25.0 \mathrm{~Hz}), 28.1$, $25.3(\mathrm{~d}, J=19.4 \mathrm{~Hz}), 21.5(\mathrm{~d}, J=9.5 \mathrm{~Hz}), 14.1$. HRMS (ESI) calc'd for $\mathrm{C}_{14} \mathrm{H}_{22} \mathrm{FNNaO}_{4}\left(\mathrm{M}+\mathrm{Na}^{+}\right)$: 310.1425, found: 310.1416.; and unseparated mixture (421 mg, 42\%). 
Ethyl (1R,3S)-3-((tert-butoxycarbonyl)amino)-4-oxocyclohexane-1-carboxylate (33). A suspension of 28 (16g, $63.41 \mathrm{mmol})$ was dispensed in EtOH (100 mL) and stirred in an ice bath. A solution of $\mathrm{NaOH}$ (2 M, $35 \mathrm{~mL}, 69.76 \mathrm{mmol}, 1.1$ equiv) was added dropwise. The ice bath was removed after the addition, and the solution was stirred at r.t. for $4 \mathrm{~h}$. The solution was concentrated below $40{ }^{\circ} \mathrm{C}$, diluted with water $(100 \mathrm{~mL})$, and extracted with DCM (200 mL) three times. The combined organic phase was washed with water $(100 \mathrm{~mL})$ and brine $(100 \mathrm{~mL})$ and dried with anhydrous $\mathrm{Na}_{2} \mathrm{SO}_{4}$. The solution was concentrated and diluted with $\mathrm{EtOH}(20 \mathrm{~mL})$ and aqueous ammonia solution $(28-30 \%, 40 \mathrm{~mL})$. The solution was heated to $45{ }^{\circ} \mathrm{C}$ and stirred overnight. The completion of the reaction was determined by LC-MS. The solution was concentrated and diluted with $\mathrm{EtOH}(50 \mathrm{~mL})$. The solution was concentrated, diluted with $\mathrm{EtOH}(200 \mathrm{~mL})$, and stirred in an ice bath. $\mathrm{Boc}_{2} \mathrm{O}$ (13.84 g, $63.41 \mathrm{mmol}, 1.0$ equiv) was added portionwise. The solution was then warmed to r.t. and stirred for $4 \mathrm{~h}$. The solution was concentrated to give crude 33. (Purification for structure determination: ${ }^{1} \mathrm{H}$ NMR $\left(500 \mathrm{MHz} \mathrm{CDCl}_{3}\right) \delta 4.61(\mathrm{~d}, J=7.0 \mathrm{~Hz}, 1 \mathrm{H}), 4.19-4.12$ (m, 2H), $3.57(\mathrm{~s}, 1 \mathrm{H}), 3.47-3.28(\mathrm{~m}, 2 \mathrm{H}), 2.62(\mathrm{p}, J=4.5 \mathrm{~Hz}, 1 \mathrm{H}), 2.35-2.26(\mathrm{~m}, 1 \mathrm{H}), 2.15-$ $2.07(\mathrm{~m}, 1 \mathrm{H}), 1.90-1.84(\mathrm{~m}, 1 \mathrm{H}), 1.55-1.48(\mathrm{~m}, 2 \mathrm{H}), 1.44(\mathrm{~s}, 10 \mathrm{H}), 1.25(\mathrm{q}, J=7.0 \mathrm{~Hz}, 3 \mathrm{H})$. ${ }^{13} \mathrm{C} \mathrm{NMR}\left(126 \mathrm{MHz}, \mathrm{CDCl}_{3}\right) \delta 174.2,171.3,80.2,73.8,60.8,53.0,38.9,31.4,30.1,28.5,24.8$, 14.4.). HRMS (ESI) calc'd for $\mathrm{C}_{14} \mathrm{H}_{25} \mathrm{~N} \mathrm{NaO}_{5}\left(\mathrm{M}+\mathrm{Na}^{+}\right)$: 310.1625, found: 310.1618 .

Crude 33 was dissolved in DCM (300 mL) and stirred in an ice bath. PCC (27.34 g, $126.83 \mathrm{mmol}$, 2.0 equiv) was added portionwise. The mixture was warmed to r.t. and stirred overnight. The completion of the reaction was determined by TLC (hexane:EtOAc $=2: 1$ ). The mixture was filtered through a thin pad of silica gel and eluted with DCM $(50 \mathrm{~mL})$ three times. The solution was concentrated and purified by silica gel chromatography (40\% EtOAc in hexane) to afford a white solid (34, $10.2 \mathrm{~g}, 56 \%) .{ }^{1} \mathrm{H}$ NMR (400 MHz, $\left.\mathrm{CDCl}_{3}\right) \delta 5.36$ (s, 1H), 4.48 (s, 1H), 4.25 (q, $J$ $=6.7 \mathrm{~Hz}, 2 \mathrm{H}), 2.99-2.91(\mathrm{~m}, 1 \mathrm{H}), 2.87(\mathrm{~s}, 1 \mathrm{H}), 2.70(\mathrm{td}, J=13.7,5.7 \mathrm{~Hz}, 1 \mathrm{H}), 2.46(\mathrm{t}, J=14.1$ $\mathrm{Hz}, 2 \mathrm{H}), 1.87(\mathrm{tt}, J=14.3,4.8 \mathrm{~Hz}, 1 \mathrm{H}), 1.62(\mathrm{td}, J=12.8,4.9 \mathrm{~Hz}, 1 \mathrm{H}), 1.43(\mathrm{~s}, 9 \mathrm{H}), 1.32(\mathrm{t}, J=$ 7.1 Hz, 3H). HRMS (ESI) calc'd for $\mathrm{C}_{14} \mathrm{H}_{23} \mathrm{NNaO}_{5}\left(\mathrm{M}+\mathrm{Na}^{+}\right)$: 308.1468, found: 308.1459.

Ethyl (1R,3S)-3-((tert-butoxycarbonyl)amino)-4,4-difluorocyclohexane-1-carboxylate (35). To a stirred suspension of XtalFluor-M (2.04 g, $8.41 \mathrm{mmol}, 2.0$ equiv) in DCM (20 mL) in a plastic container was slowly added a solution of 34 (1.2 g, $4.21 \mathrm{mmol}, 1.0$ equiv) and $(\mathrm{HF})_{3} \mathrm{Et}_{3} \mathrm{~N}(1.36 \mathrm{~g}$, $8.41 \mathrm{mmol}, 2.0$ equiv) in DCM (10 mL) under Ar. After the addition was completed, the mixture was stirred at r.t. overnight. The completion of reaction was determined by TLC (hexane: EtOAc 
$=2: 1)$. The reaction was diluted with DCM $(30 \mathrm{~mL})$ and quenched with water $(10 \mathrm{~mL})$. The organic

phase was separated and then washed with water $(10 \mathrm{~mL}), \mathrm{NaHCO}_{3}$ (aq. $\left.10 \mathrm{~mL}\right)$, and brine $(10$ $\mathrm{mL}$ ). The organic phase was dried with anhydrous $\mathrm{Na}_{2} \mathrm{SO}_{4}$. The solution was concentrated and purified by silica gel chromatography (20\% EtOAc in hexane) to afford a white solid (35, $629 \mathrm{mg}$, 48\%). ${ }^{1} \mathrm{H}$ NMR (500 MHz, $\left.\mathrm{CDCl}_{3}\right) \delta 4.68(\mathrm{~s}, 1 \mathrm{H}), 4.18(\mathrm{q}, J=7.1 \mathrm{~Hz}, 2 \mathrm{H}), 4.12(\mathrm{~s}, 1 \mathrm{H}), 2.71$ (s, $1 \mathrm{H}), 2.31(\mathrm{~d}, J=12.3 \mathrm{~Hz}, 1 \mathrm{H}), 2.14-1.90(\mathrm{~m}, 3 \mathrm{H}), 1.81-1.72(\mathrm{~m}, 1 \mathrm{H}), 1.71-1.65(\mathrm{~m}, 1 \mathrm{H}), 1.45$ (s, 9H), $1.28(\mathrm{t}, J=7.1 \mathrm{~Hz}, 3 \mathrm{H}) .{ }^{13} \mathrm{C} \mathrm{NMR}\left(126 \mathrm{MHz}, \mathrm{CDCl}_{3}\right) \delta{ }^{13} \mathrm{C} \mathrm{NMR}\left(126 \mathrm{MHz}, \mathrm{CDCl}_{3}\right) \delta$ 173.5, 155.2, $121.6(\mathrm{dd}, J=248.2,242.0 \mathrm{~Hz}), 80.1,61.1,50.1(\mathrm{dd}, J=25.0,21.0 \mathrm{~Hz}), 37.9,31.5$, 30.4 (t, $J=23.3 \mathrm{~Hz}$ ), 28.4, $23.8(\mathrm{~d}, J=7.9 \mathrm{~Hz}), 14.4$. HRMS (ESI) calc'd for $\mathrm{C}_{14} \mathrm{H}_{23} \mathrm{~F}_{2} \mathrm{NNaO}_{4}$ $\left(\mathrm{M}+\mathrm{Na}^{+}\right)$: 330.q1487, found: 330.1479 .

\section{Ethyl (S)-3-((tert-butoxycarbonyl)amino)-4,4-difluorocyclohex-1-ene-1-carboxylate (36a) \& ethyl ( $S$ )-5-((tert-butoxycarbonyl)amino)-4,4-difluorocyclohex-1-ene-1-carboxylate (36b). A} stirred solution of KHMDS ( $1 \mathrm{M}$ in THF, $7.16 \mathrm{~mL}, 7.16 \mathrm{mmol}, 2.2$ equiv) was diluted in dry THF $(5 \mathrm{~mL})$ and cooled to $-78{ }^{\circ} \mathrm{C}$ under Ar; then a solution of $\mathbf{3 5}(1.0 \mathrm{~g}, 3.25 \mathrm{mmol}, 1.0$ equiv) in dry THF $(10 \mathrm{~mL})$ was slowly added over $30 \mathrm{~min}$. The solution was stirred at $-78^{\circ} \mathrm{C}$ for an additional $3 \mathrm{~h}$, followed by the addition of a solution of $\mathrm{PhSeCl}$ ( $685 \mathrm{mg}, 3.58 \mathrm{mmol}, 1.1$ equiv) in THF (10 $\mathrm{mL})$. The solution was then slowly warmed to r.t. and stirred overnight. The reaction was quenched with the addition of sat. $\mathrm{NH}_{4} \mathrm{Cl}(20 \mathrm{~mL})$. The solution was then diluted with EtOAc $(200 \mathrm{~mL})$, and the organic phase was separated. The aqueous phase was extracted with EtOAc $(100 \mathrm{~mL})$ twice. The combined organic phase was washed with brine $(c a .30 \mathrm{~mL})$ and dried with anhydrous $\mathrm{Na}_{2} \mathrm{SO}_{4}$. The solution was concentrated to give a yellow oil. To a stirred solution of the oil in DCM $(20 \mathrm{~mL})$ was added $m$-CPBA ( $555 \mathrm{mg}, 2.48 \mathrm{mmol}, 1.5$ equiv). The solution was stirred at r.t. for $3 \mathrm{~h}$. The completion of the reaction was determined by LC-MS. The reaction was quenched with $\mathrm{Na}_{2} \mathrm{~S}_{2} \mathrm{O}_{3}$ (aq. $10 \mathrm{~mL}$ ). The organic phase was separated, washed with saturated $\mathrm{NaHCO}_{3}$ (aq. $10 \mathrm{~mL}$ ) and brine $(10 \mathrm{~mL})$, and dried with anhydrous $\mathrm{Na}_{2} \mathrm{SO}_{4}$. The solution was concentrated and purified by silica gel chromatography (5-10\% EtOAc in hexane) to afford a white solid (36a, $258 \mathrm{mg}, 51 \%$ ), ${ }^{1} \mathrm{H}$ NMR (400 MHz, $\left.\mathrm{CDCl}_{3}\right) \delta 6.59(\mathrm{ddt}, J=5.2,2.6,1.3 \mathrm{~Hz}, 1 \mathrm{H}), 4.90-4.168(\mathrm{~m}, 2 \mathrm{H}), 4.21(\mathrm{q}$, $J=7.1 \mathrm{~Hz}, 2 \mathrm{H}), 2.70-2.57(\mathrm{~m}, 1 \mathrm{H}), 2.57-2.43(\mathrm{~m}, 1 \mathrm{H}), 2.28$ (tdd, $J=16.6,8.6,4.5 \mathrm{~Hz}, 1 \mathrm{H})$, $2.17-1.97(\mathrm{~m}, 1 \mathrm{H}), 1.47(\mathrm{~s}, 9 \mathrm{H}), 1.30(\mathrm{t}, J=7.1 \mathrm{~Hz}, 3 \mathrm{H}) .{ }^{13} \mathrm{C} \mathrm{NMR}\left(126 \mathrm{MHz}, \mathrm{CDCl}_{3}\right) \delta 165.8$, 155.4, 135.6, 131.9, $120.2(\mathrm{dd}, J=247.1,241.3 \mathrm{~Hz}), 80.7,61.2,51.4(\mathrm{t}, J=26.8,22.4 \mathrm{~Hz}), 29.5$ (t, $J=23.5 \mathrm{~Hz}), 28.4,22.8(\mathrm{dd}, J=7.6,2.9 \mathrm{~Hz}), 14.3 .{ }^{19} \mathrm{~F} \mathrm{NMR}\left(376 \mathrm{MHz}, \mathrm{CDCl}_{3}\right) \delta-105.13(\mathrm{~d}$, 
$J=239.4 \mathrm{~Hz}),-115.81(\mathrm{~d}, J=239.3 \mathrm{~Hz})$, HRMS $(\mathrm{ESI})$ calc'd for $\mathrm{C}_{14} \mathrm{H}_{21} \mathrm{~F}_{2} \mathrm{NNaO}_{4}\left(\mathrm{M}+\mathrm{Na}^{+}\right)$: 328.1331, found: 328.1324 .

Another white solid (36b, $62 \mathrm{mg}, 12 \%)$ also was obtained. ${ }^{1} \mathrm{H}$ NMR $\left(500 \mathrm{MHz}, \mathrm{CDCl}_{3}\right) \delta 6.76(\mathrm{~s}$, $1 \mathrm{H}), 4.83-4.67(\mathrm{~m}, 1 \mathrm{H}), 4.21$ (q, $J=7.1 \mathrm{~Hz}, 2 \mathrm{H}), 4.18-4.14(\mathrm{~m}, 1 \mathrm{H}), 2.95(\mathrm{~d}, J=17.5 \mathrm{~Hz}, 1 \mathrm{H})$, $2.90-2.70(\mathrm{~m}, 2 \mathrm{H}), 2.40-2.28(\mathrm{~m}, 1 \mathrm{H}), 1.46(\mathrm{~s}, 9 \mathrm{H}), 1.29(\mathrm{t}, J=7.1 \mathrm{~Hz}, 3 \mathrm{H}) .{ }^{13} \mathrm{C}$ NMR $(126$ $\left.\mathrm{MHz}, \mathrm{CDCl}_{3}\right) \delta 165.6,155.4,132.8(\mathrm{~d}, J=9.1 \mathrm{~Hz}), 129.0,120.5(\mathrm{dd}, J=246.9,242.0 \mathrm{~Hz}), 80.4$, 61.1, $49.5(\mathrm{t}, J=21.5 \mathrm{~Hz}), 34.8(\mathrm{t}, J=28.1 \mathrm{~Hz}), 30.3(\mathrm{t}, J=3.6 \mathrm{~Hz}), 28.4$, 14.3., HRMS (ESI) calc'd for $\mathrm{C}_{14} \mathrm{H}_{21} \mathrm{~F}_{2} \mathrm{NNaO}_{4}\left(\mathrm{M}+\mathrm{Na}^{+}\right)$: 328.1331, found: 328.1324.; and unseparated mixture of $\mathbf{3 6 a}$ and 36b (94 mg, 19\%).

General deprotection procedure $\mathbf{A}$. To a solution of aq. $\mathrm{HCl}(4 \mathrm{M}, 1.5 \mathrm{~mL})$ and $\mathrm{AcOH}(1.5 \mathrm{~mL})$ was added the ester intermediate under Ar. The solution was sealed and heated to $80{ }^{\circ} \mathrm{C}$ and stirred overnight. The completion of the reaction was determined by LC-MS. The solution was concentrated and purified by $\mathrm{C}-18$ chromatography to give the product.

(3S,4S)-3-Amino-4-fluorocyclohex-1-ene-1-carboxylic acid hydrochloride (8). 32a (150 mg, $0.522 \mathrm{mmol}$ ) was deprotected by procedure A to give a white solid $(\mathbf{8}, 94 \mathrm{mg}, 92 \%) .{ }^{1} \mathrm{H}$ NMR (500 $\left.\mathrm{MHz}, \mathrm{CD}_{3} \mathrm{OD}\right) \delta 6.67(\mathrm{dt}, J=5.1,2.5 \mathrm{~Hz}, 1 \mathrm{H}), 4.78(\mathrm{dddd}, J=50.5,11.6,7.8,4.0 \mathrm{~Hz}, 1 \mathrm{H}), 4.27$ $-4.13(\mathrm{~m}, 1 \mathrm{H}), 2.65(\mathrm{~d}, J=20.3 \mathrm{~Hz}, 1 \mathrm{H}), 2.50-2.39(\mathrm{~m}, 1 \mathrm{H}), 2.33-2.23(\mathrm{~m}, 1 \mathrm{H}), 1.98(\mathrm{ddq}, J$ $=17.5,11.9,6.0 \mathrm{~Hz}, 1 \mathrm{H}) .{ }^{13} \mathrm{C} \mathrm{NMR}\left(126 \mathrm{MHz}, \mathrm{CD}_{3} \mathrm{OD}\right) \delta 168.2,137.2(\mathrm{~d}, J=2.4 \mathrm{~Hz}), 130.5(\mathrm{~d}$, $J=7.0 \mathrm{~Hz}), 90.9(\mathrm{~d}, J=177.6 \mathrm{~Hz}), 53.6(\mathrm{~d}, J=23.2 \mathrm{~Hz}), 27.3(\mathrm{~d}, J=18.7 \mathrm{~Hz}), 24.4(\mathrm{~d}, J=11.2$ Hz). ${ }^{13} \mathrm{C}$ NMR (126 MHz, CD $\left.\mathrm{CD}_{3} \mathrm{OD}\right) \delta 168.4,136.3(\mathrm{~d}, J=11.1 \mathrm{~Hz}), 128.4,89.8(\mathrm{~d}, J=177.5 \mathrm{~Hz})$, $51.7(\mathrm{~d}, J=18.1 \mathrm{~Hz}), 31.8(\mathrm{~d}, J=21.7 \mathrm{~Hz}), 29.2(\mathrm{~d}, J=6.1 \mathrm{~Hz})$. HRMS (ESI) calc'd for $\mathrm{C}_{7} \mathrm{H}_{11} \mathrm{FNO}_{2}$ $\left(\mathrm{M}+\mathrm{H}^{+}\right): 160.0768$, found: 160.0765 .

(S)-3-Amino-4,4-difluorocyclohex-1-ene-1-carboxylic acid hydrochloride (9). 36a (105 mg, $0.34 \mathrm{mmol}$ ) was deprotected by procedure A to give a white solid $(\mathbf{9}, 56 \mathrm{mg}, 76 \%) .{ }^{1} \mathrm{H}$ NMR (500 $\left.\mathrm{MHz}, \mathrm{CD}_{3} \mathrm{OD}\right) \delta 6.72(\mathrm{~s}, 1 \mathrm{H}), 4.65-4.52(\mathrm{~m}, 1 \mathrm{H}), 2.71(\mathrm{ddd}, J=18.9,6.2,3.0 \mathrm{~Hz}, 1 \mathrm{H}), 2.55(\mathrm{dtd}$, $J=19.0,6.4,3.1 \mathrm{~Hz}, 1 \mathrm{H}), 2.47-2.22(\mathrm{~m}, 2 \mathrm{H}) .{ }^{13} \mathrm{C} \mathrm{NMR}\left(126 \mathrm{MHz}, \mathrm{CD}_{3} \mathrm{OD}\right) \delta 167.9,136.8$, $129.62(\mathrm{~d}, J=5.9 \mathrm{~Hz}), 121.05(\mathrm{t}, J=246.2 \mathrm{~Hz}), 52.27(\mathrm{dd}, J=29.1,22.2 \mathrm{~Hz}), 29.24(\mathrm{t}, J=22.7$ $\mathrm{Hz}), 23.76(\mathrm{dd}, J=7.7,2.9 \mathrm{~Hz}) .{ }^{19} \mathrm{~F}$ NMR $\left(376 \mathrm{MHz}, \mathrm{CD}_{3} \mathrm{OD}\right) \delta-108.4(\mathrm{dp}, J=240.6,5.8,5.3$ $\mathrm{Hz}$ ), $-114.2\left(\mathrm{dq}, J=240.7,23.2 \mathrm{~Hz}\right.$ ). HRMS (ESI) calc'd for $\mathrm{C}_{7} \mathrm{H}_{10} \mathrm{~F}_{2} \mathrm{NO}_{2}\left(\mathrm{M}+\mathrm{H}^{+}\right)$: 178.0674 , found: 178.0672 . 
(4S,5S)-5-Amino-4-fluorocyclohex-1-ene-1-carboxylic acid hydrochloride (10). $32 \mathrm{~b}$ (80 mg, $0.278 \mathrm{mmol})$ was deprotected by procedure A to give a white solid (10, $49 \mathrm{mg}, 90 \%)$. ${ }^{1} \mathrm{H} \mathrm{NMR}$ $\left(500 \mathrm{MHz}, \mathrm{CD}_{3} \mathrm{OD}\right) \delta 6.89(\mathrm{~s}, 1 \mathrm{H}), 5.02-4.95(\mathrm{~m}, 1 \mathrm{H}), 3.65(\mathrm{tt}, J=10.6,6.2 \mathrm{~Hz}, 1 \mathrm{H}), 3.03(\mathrm{dt}, J$ $=17.3,5.8 \mathrm{~Hz}, 1 \mathrm{H}), 2.93(\mathrm{~d}, J=18.5 \mathrm{~Hz}, 1 \mathrm{H}), 2.65-2.51(\mathrm{~m}, 1 \mathrm{H}), 2.51-2.38(\mathrm{~m}, 1 \mathrm{H}) .{ }^{13} \mathrm{C} \mathrm{NMR}$ (126 MHz, CD 3 OD) $\delta 168.4,136.3(\mathrm{~d}, J=11.1 \mathrm{~Hz}), 128.4,89.8$ (d, $J=177.5 \mathrm{~Hz}), 51.7$ (d, $J=18.1$ $\mathrm{Hz}), 31.8(\mathrm{~d}, J=21.7 \mathrm{~Hz}), 29.2(\mathrm{~d}, J=6.1 \mathrm{~Hz})$. HRMS (ESI) calc'd for $\mathrm{C}_{7} \mathrm{H}_{11} \mathrm{FNO}_{2}\left(\mathrm{M}+\mathrm{H}^{+}\right)$: 160.0768, found: 160.0762 .

(S)-5-Amino-4,4-difluorocyclohex-1-ene-1-carboxylic acid hydrochloride (11). $36 \mathrm{~b}$ (30 mg, $0.10 \mathrm{mmol})$ was deprotected by procedure A to give a white solid (11, $14 \mathrm{mg}, 66 \%) .{ }^{1} \mathrm{H}$ NMR (500 $\left.\mathrm{MHz}, \mathrm{CD}_{3} \mathrm{OD}\right) \delta 6.87(\mathrm{p}, J=3.9 \mathrm{~Hz}, 1 \mathrm{H}), 4.06-3.95(\mathrm{~m}, 1 \mathrm{H}), 3.15-3.06(\mathrm{~m}, 1 \mathrm{H}), 3.00(\mathrm{dp}, J=$ 21.4, 4.1, 3.2 Hz, 2H), $2.53(\mathrm{ddd}, J=17.1,10.6,2.8 \mathrm{~Hz}, 1 \mathrm{H}) .{ }^{13} \mathrm{C} \mathrm{NMR}\left(126 \mathrm{MHz}, \mathrm{CD}_{3} \mathrm{OD}\right) \delta$ 167.9, $134.4(\mathrm{~d}, J=10.3 \mathrm{~Hz}), 128.3,121.1(\mathrm{dd}, J=245.6,243.5 \mathrm{~Hz}), 50.9$ (t, $J=22.5 \mathrm{~Hz}), 34.9$ (t, $J=25.6 \mathrm{~Hz}$ ), 28.6. HRMS (ESI) calc'd for $\mathrm{C}_{7} \mathrm{H}_{10} \mathrm{~F}_{2} \mathrm{NO}_{2}\left(\mathrm{M}+\mathrm{H}^{+}\right)$: 178.0674, found: 178.0675 .

\section{Docking Simulation}

Docking models of ligands bound to GABA-AT or OAT were developed using the Molecular Operating Environment (MOE) computational suite's Builder utility. ${ }^{1-3}$ The energy minimization of ligands was conducted in the gas phase using the force field MMFF94X, followed by the Conformational Search protocol to generate structural-conformation databases. The X-ray crystal structures of native GABA-AT (PDB: 1OHV), native hOAT (1OAT), inactivated GABA-AT (4YOI) and inactivated $h \mathrm{OAT}(1 \mathrm{GBN})$ were uploaded to MOE respectively, followed by the receptor preparation. The tight-binding products in the active pocket of 5VWO and 4Y0I was deleted, and catalytic Lys was neutralized. The docking sites were specified at the catalytic Lys atoms. Ligand dockings were carried out in the prepared aminotransferase enzyme models with unrelated substrates and the solvent atoms inactivated. Ligand placement employed the Alpha Triangle method with Affinity dG scoring generating 300 data points that were further refined using the induced fit method with GBVI/WSA dG scoring to obtain the top 50 docking results. The docking results of each ligand were analyzed for selection of the best docking pose, based on the score and reported X-ray structures. All renderings were then performed in PyMOL.

\section{Enzyme Assays}


hOAT and PYCR1 were expressed, grown, and purified according to literature procedures. ${ }^{4,5}$ GABA-AT was isolated from pig brains and purified according to a literature procedure. ${ }^{6}$ Coupled enzyme assays for GABA-AT, hOAT, Ala-AT, and Asp-AT were carried out according to previous procedures. ${ }^{7,8}$

\section{Dialysis Assay}

The dialysis experiment was conducted using previous protocols. ${ }^{7,9,10}$

\section{Partition Ratio Experiment}

The partition ratio was calculated using previous protocols. ${ }^{7,9,10}$

\section{Fluoride Ion Release}

The fluoride ion release assay was conducted using previous protocols. ${ }^{7}$ The final concentration of $h \mathrm{OAT}$ in the sample was determined to be $16.9 \pm 0.04 \mathrm{ug} / \mathrm{mL}$ (monomer, $0.37 \pm 0.01 \mu \mathrm{M}$ ) via BSA assay and calculation of dilution. A calibration curve of voltage $(V, \mathrm{mV})$ was generated from varying concentrations of $\mathrm{NaF}(F, \mu \mathrm{M})$ to get the equation: $F^{-}=10^{\wedge}((V-181.9) /-53.18)$. For accurate detection of fluoride ion concentration, $2.0 \mu \mathrm{M}$ of fluoride ion was added to each control and sample. The number of fluoride ions released per active site was calculated by the ratio of the fluoride ion release concentration and $h \mathrm{OAT}$ concentration.

\section{Intact Protein and Small Molecule Mass Spectrometry}

Recombinant and treated $h \mathrm{OAT}$ were desalted ten times with water on Amicon Ultra $30 \mathrm{kDa}$ molecular weight spin filters (Millipore). To chromatographically resolve $h \mathrm{OAT}, 0.5 \mu \mathrm{g}$ of $h \mathrm{OAT}$ was loaded onto a $3 \mathrm{~cm}$ PLRP-S (Agilent) trap column using a Dionex Ultimate3000 liquid chromatography system (Thermo Fisher). The protein analyte was washed with a 10-min isocratic gradient of 10\% Solvent B (95\% MeCN/5\% $\mathrm{H}_{2} \mathrm{O} / 0.2 \%$ FA) and 90\% Solvent A (5\% MeCN/95\% $\mathrm{H}_{2} \mathrm{O} / 0.2 \% \mathrm{FA}$ ). $h \mathrm{OAT}$ was resolved on an in-house made $75 \mu \mathrm{m}$ ID x $15 \mathrm{~cm}$ long nanopore capillary column packed with PLRP-S resin (Agilent). The LC system was operated at a flow rate of $300 \mathrm{~nL} / \mathrm{min}$ at the following gradient: 0-10 min 10\% Solvent B; 10-12 min to $40 \%$ Solvent B; 12-22 min to $90 \%$ Solvent B; $22-24$ min at $90 \%$ Solvent B; 24-26 min to $10 \%$ Solvent B; $26-30$ min isocratic at $10 \%$ Solvent B. Positive, full-profile ESI data were acquired in the Orbitrap mass analyzers on a Fusion Lumos Tribrid mass spectrometer (Thermo Fisher) operated in low pressure, protein mode, with a $\left[\mathrm{M}+24 \mathrm{H}^{+}\right]^{+24}$ default charge state. A custom nano-electrospray ionization 
source was used with a static spray voltage of $1700 \mathrm{~V}$. Data were collected in a 500-2,000 m/z window, averaging 20 micro scans per scan event at a resolving power of 7,500 at $(200 \mathrm{~m} / \mathrm{z})$ with a maximum injection time of $50 \mathrm{~ms}$ and a target value for the automatic gain control (AGC) of 5e6 charges. Averaged summed scans were manually deconvoluted to generate neutral masses. Small molecule and metabolite masses were identified and characterized by high-resolution LC-MS/MS on a Q-Exactive Orbitrap mass spectrometer as previously described. ${ }^{9}$

\section{0. hOAT crystallization}

\section{Crystal Structure Growth}

The freshly prepared enzyme $(200 \mu \mathrm{g})$ was dialyzed with $50 \mathrm{mM}$ potassium pyrophosphate which contained $5 \mathrm{mM} \alpha$-ketoglutarate at $\mathrm{pH}$ 8.0. Compound $\mathbf{8} / \mathbf{9}(0.5 \mathrm{mg})$ was added and the enzyme was inactivated in a vial covered with foil for $12 \mathrm{~h}$. The coupled enzyme assay indicated no activity. After complete inactivation of hOAT activity, the enzyme sample was concentrated in $50 \mathrm{mM}$ tricine $p \mathrm{H} 7.8$ to a protein concentration of $6 \mathrm{mg} / \mathrm{mL}$. Crystallization was optimized via the hanging drop vapor diffusion method and was set by varying PEG 1000 (10-20\%), $\mathrm{NaCl}$ (100-250 mM), glycerol (20\%-30\%) $50 \mathrm{mM}$ tricine $p \mathrm{H} 7.8 \mathrm{kept}$ constant as the buffer. For each well, a 1:1 ratio of drop of well: protein solution was set. The crystals with the best morphology and size for data collection grew in wells containing 16.5\% PEG 1000, $240 \mathrm{mM} \mathrm{NaCl}, 25 \%$ glycerol. Crystals were transferred to a cryo-protectant solution (well solution supplemented with $30 \%$ glycerol) before being flash frozen in liquid nitrogen.

\section{Data Collection and Processing}

Monochromatic data were collected at the LS-CAT beamline 21-ID-D, Advanced Photon Source (APS) at Argonne National Laboratory (ANL). Diffraction data were collected at a wavelength of $0.98 \AA$ at $100 \mathrm{~K}$ using a Dectris Eiger 9M detector. Data sets were indexed and integrated using the HKL2000 ${ }^{11}$ suite. Data statistics are summarized in Table S1.

\section{Model Building and Refinement}

The hOAT structure was solved by molecular replacement using PHASEER in the Phenix software suite. $^{12}$ The first search model was based on a previously published structure of $h \mathrm{OAT}$ (PDB code: 1OAT). The model was rebuilt using COOT,${ }^{13}$ refined using Phenix, and analyzed in COOT and 
USCF Chimera. ${ }^{14}$ Final refinement statistics are reported in Table S1. Structural figures were made in USCF Chimera.

\section{Molecular Dynamics Simulation}

A docking protocol was employed to generate the initial $h \mathrm{OAT}$ complex corresponding to $14 \mathrm{a}$ and 14b for the classical MD simulation. The protein structure chosen for this study was the X-ray crystal structure of inactivated $h \mathrm{OAT}$ (PDB ID: $1 \mathrm{GBN}$ ) with a resolution of $2.3 \AA$. The protonation states of the amino acid residues were determined using the $\mathrm{H}++$ server. The structures of $\mathbf{1 4 a}$ and 14b were optimized using Gausian09 software at a HF/6-31+(G) level of theory. ${ }^{15}$ The inhibitor and protein structures were further refined using AutoDockTools-1.5.6 available with the MGLTools software package. ${ }^{16}$ Refined inhibitor structures were docked into the OAT active site using Autodock 4.2 software. A gridbox centered on the active site was generated using Autogrid 4.2 software with a grid spacing of $0.375 \AA$ and dimensions of $55 \times 55 \times 55$ points along the $\mathrm{x}, \mathrm{y}$, and $\mathrm{z}$ axes. Lamarckian genetic algorithm (GA) was used for the conformational search with a GA population size of 150 and a maximum number of evaluations of 2500000 . The 100 generated

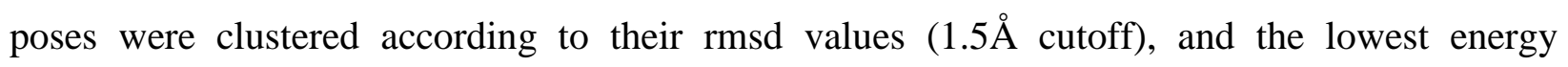
conformation of the best cluster was selected for the MD simulation. The electrostatic potential energies (ESP) of the geometrically optimized inhibitors $(\mathrm{HF} / 6-31+\mathrm{G})$ were calculated at the $\mathrm{HF} / 6-31+\mathrm{G}$ level of theory. Then these energies were used to derive the partial atomic charges of the inhibitors using the electrostatic potential square fit (ESP) method employed in the antechamber module available in the Amber 12 program. ${ }^{17}$ This is the method used to derive the partial atomic charges of the original Amber forcefields. The inhibitor atoms were treated with general Amber force field (GAFF), and the automatically assigned GAFF atom types were manually adjusted to accurately represent their chemical environment before deriving the parameters. The parameters and topology files were generated using tLEaP and antechamber modules of the Amber12 program. Then these parameters and topology files were converted to GROMACS compatible format using ACPYPE. ${ }^{18}$ The forcefield parameters and the topology for covalently bound PLP were derived similarly. The modified Amberff99SB-ILDN forcefield with parameters for covalently bound PLP were used to simulate the protein. Parameters for the OAT dimer were derived using the PDB2gmx module available in the GROMACS 5.1.2 software package. All of the MD simulations were performed using GROMACS 5.1.2 software. ${ }^{19}$ The TIP3P model was used as the water model. The protein-inhibitor complex was immersed in a 
dodecahedron box filled with TIP3P water where the boundaries are extending at least $1.8 \mathrm{~nm}$ in all directions from the edges of the protein. Then, $\mathrm{NaCl}$ was added to the system up to a concentration of $0.15 \mathrm{M}$ (physiological $\mathrm{NaCl}$ concentration) to neutralize the charge of the system. The solvated system was energy minimized with the steepest descent followed by the conjugate gradient method until it converged with a maximum force no greater than $500 \mathrm{KJ} \mathrm{mol}^{-1} \mathrm{~nm}^{-1}$.

The resulting energy minimized periodic system was the starting configuration for the MD simulation, which was carried out with the aid of the Extreme Science and Engineering Discovery Environment (XSEDE) ${ }^{20}$ Prior to the production MD simulation, the system was subjected to equilibration in two steps. First, it was equilibrated at constant NVT (number of particles, volume, and temperature) ensemble for $1 \mathrm{~ns}$. Then the resulting system was equilibrated at constant NPT (number of particles, pressure, and temperature) ensemble for $3 \mathrm{~ns}$. Temperature and pressure were controlled at $310 \mathrm{~K}$ and 1 bar by the V-rescale thermostat (time constant of $0.4 \mathrm{ps}$ ) and the Parrinello-Rahmanbarostat (time constant of $2 \mathrm{ps}$ ), respectively. In both equilibration steps, positions of the heavy atoms were restrained by applying a force constant of $1000 \mathrm{KJ} \mathrm{mol}^{-1} \mathrm{~nm}^{-2}$. After that, the position restraints were gradually reduced from 500 to $100 \mathrm{KJ} \mathrm{mol}^{-1} \mathrm{~nm}^{-2}$ over two runs (1 ns each). Finally, a production MD simulation of the equilibrated system was carried out under the NPT condition for $15 \mathrm{~ns}$ (time step of $2 \mathrm{fs}$ ) without positional restraints. During the NPT equilibration, the V-rescale thermostat was replaced by the most accurate Nosé-Hoover thermostat and used for the rest of the simulation protocol. The long-range electrostatic interactions were treated with the particle mesh Ewald (PME) method, while Coulomb and van der Waals interactions were cut off at $1.2 \mathrm{~nm}$. Bond lengths of the atoms were restrained using the Linear Constraint Solver (LINCS) algorithm.

Important distance and dihedral angle measurements were taken using distance, mindist and angle tools available in the GROMACS software package.

\section{Electrostatic Potential (ESP) Charge Calculation}

The electrostatic potential (ESP) energies and the charges of the geometrically optimized inhibitors (14a and 14b) $(\mathrm{HF} / 6-31+\mathrm{G})$ in gas phase were calculated at the HF/6-31+G level of theory. Cubegen utility of the Gaussain09 program was used to generate the electron density and electrostatic potential maps and visualized using VMD 1.9.2 molecular visualization program. 


\section{2D NMR Spectrum}
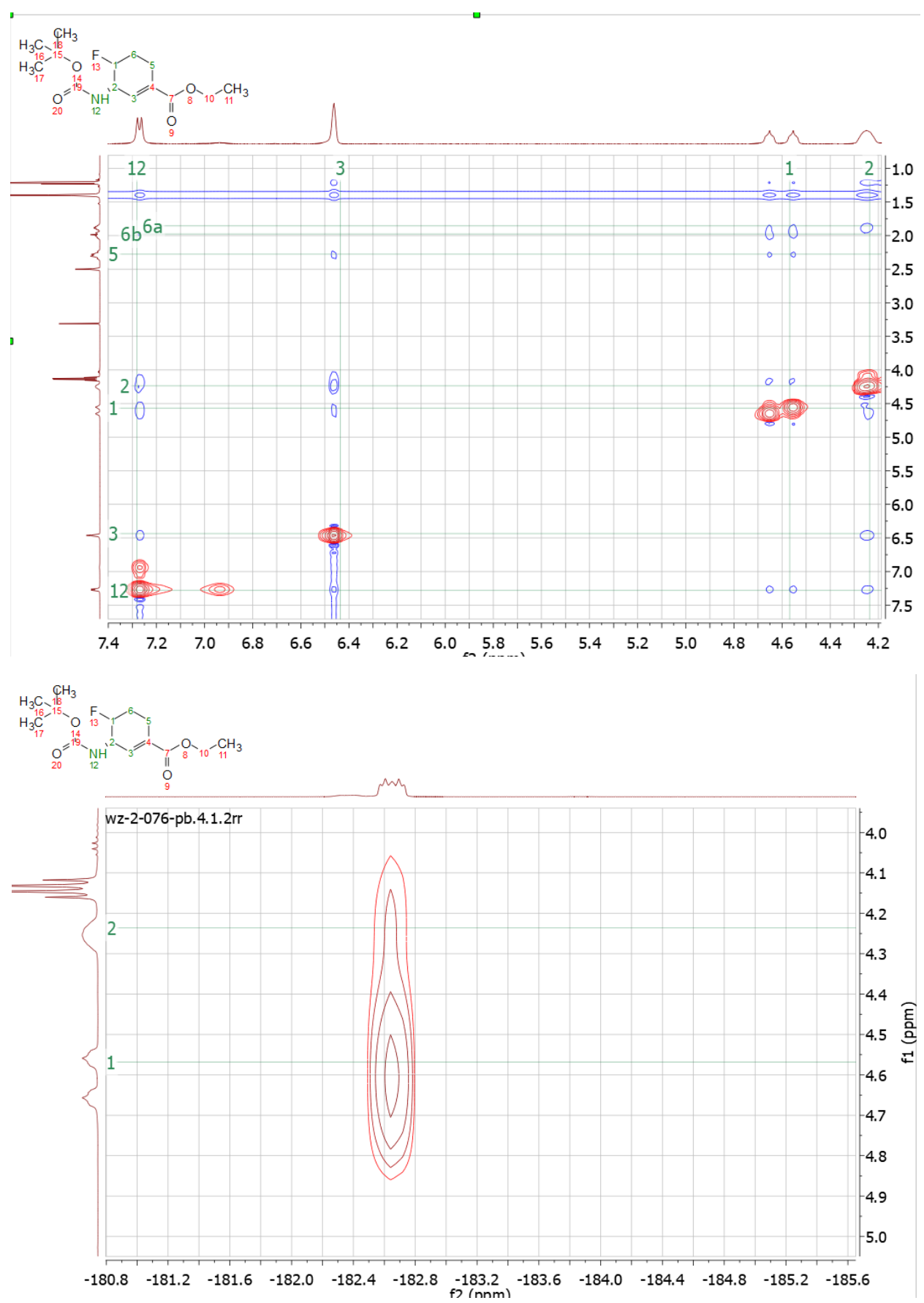

NOESY spectrum (left, H-H interaction) and HOESY spectrum (right, H-F interaction) of 32a for structure determination. 


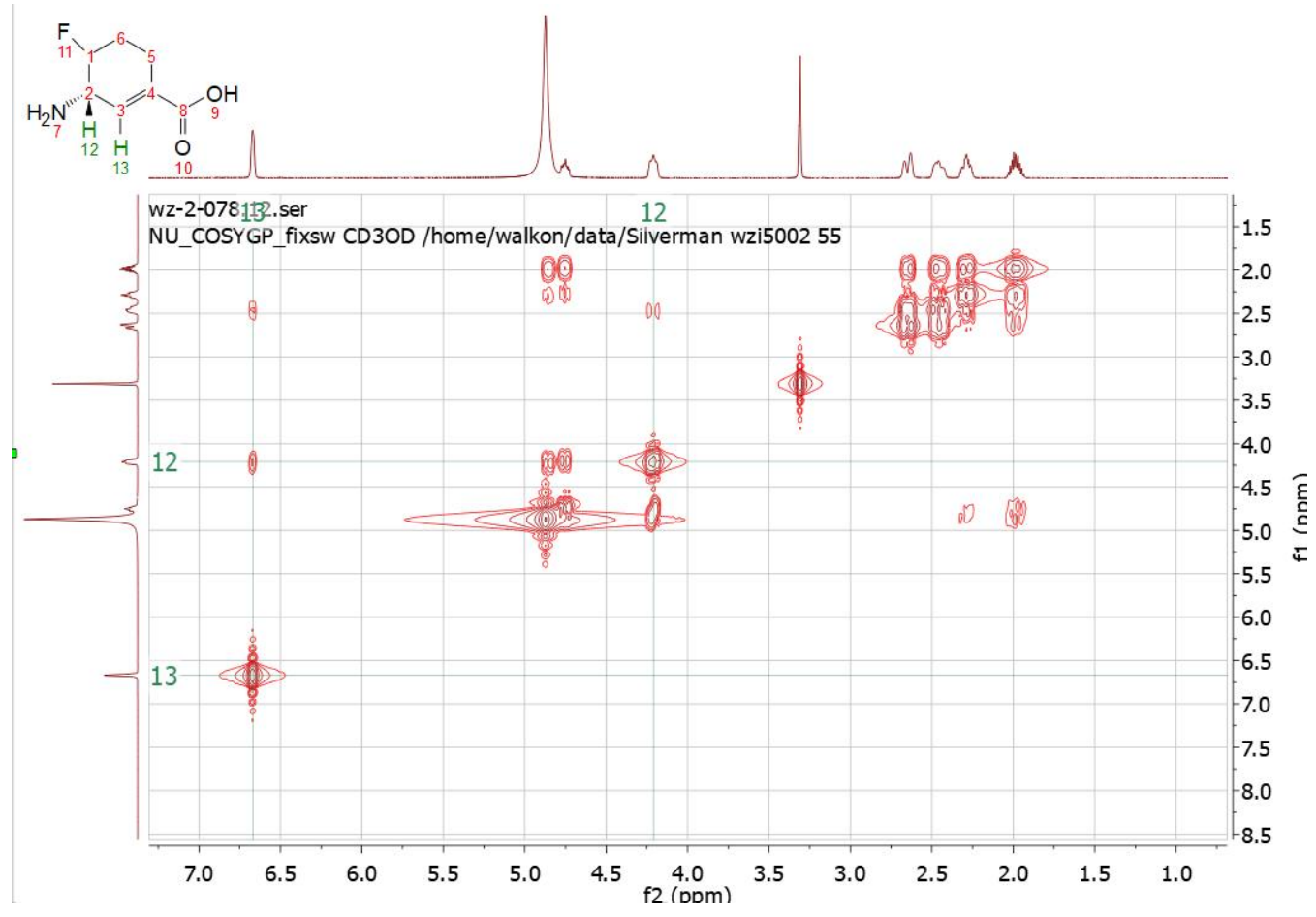

COSY spectrum (H-H coupling) of $\mathbf{8}$ for structure determination

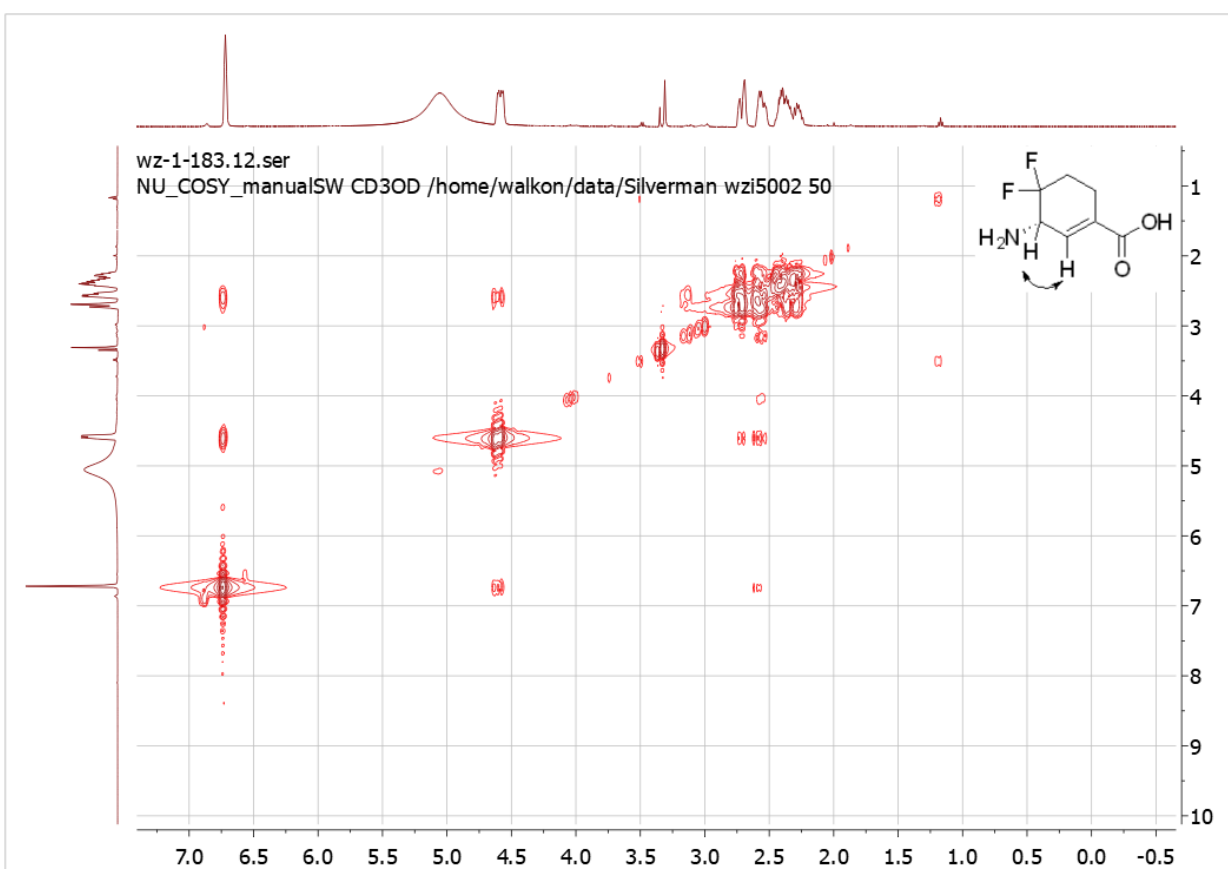

COSY spectrum ( $\mathrm{H}-\mathrm{H}$ coupling) of $\mathbf{9}$ for structure determination 


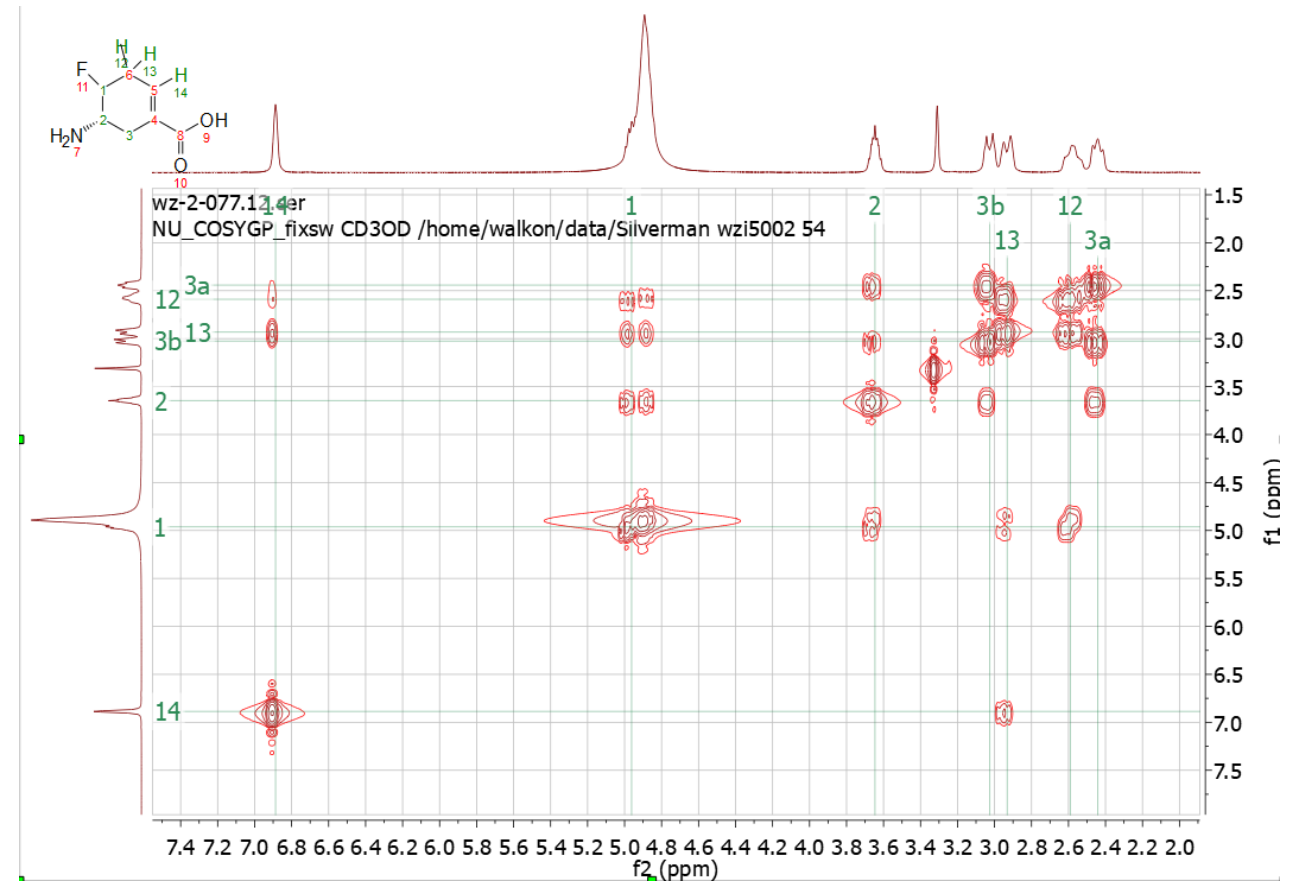

COSY spectrum (H-H coupling) of $\mathbf{1 0}$ for structure determination

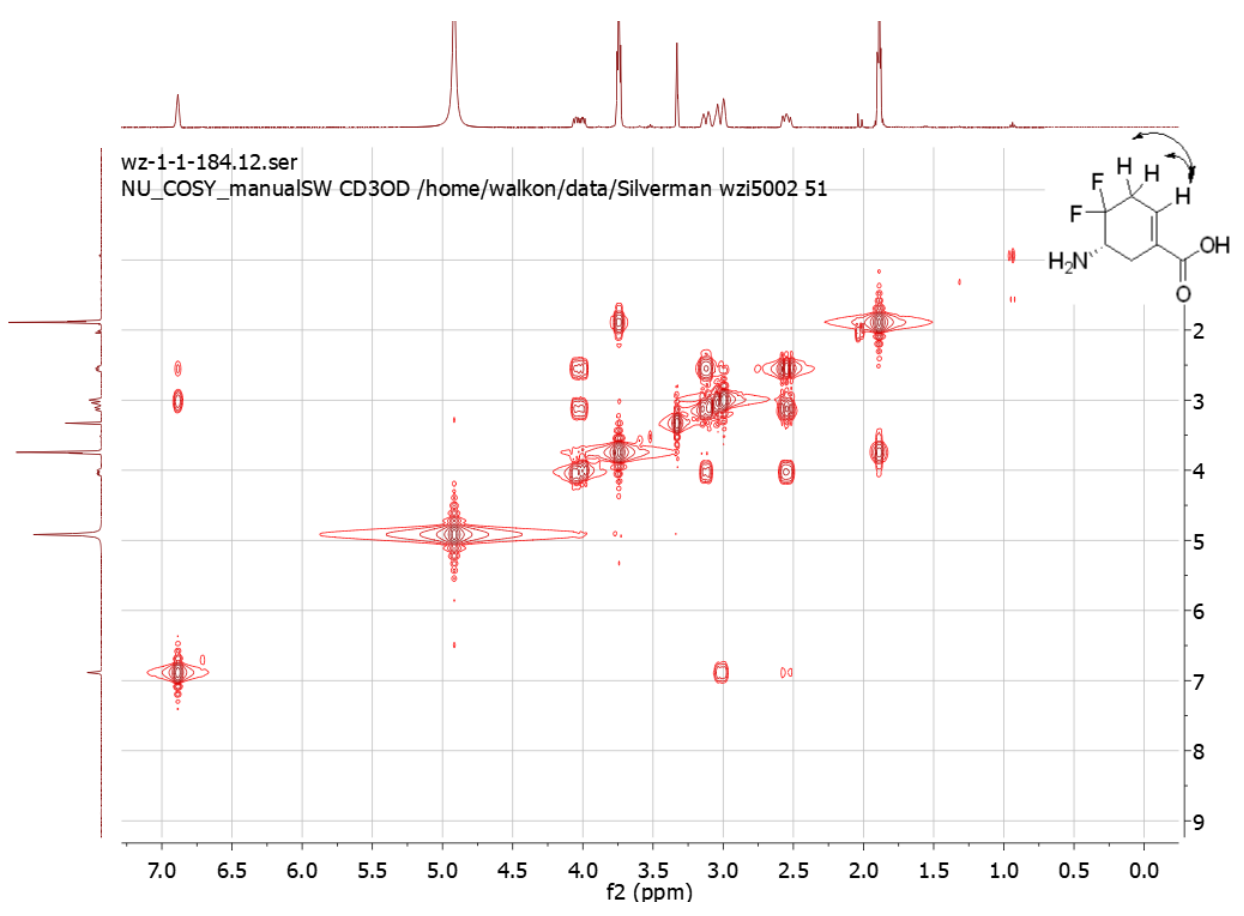

COSY spectrum (H-H coupling) of $\mathbf{1 1}$ for structure determination 


\section{References}

1. Heath, T. K.; Lutz, M. R.; Reidl, C. T.; Guzman, E. R.; Herbert, C. A.; Nocek, B. P.; Holz, R. C.; Olsen, K. W.; Ballicora, M. A.; Becker, D. P., Practical Spectrophotometric Assay for the dapE-encoded N-succinyl-L, L-diaminopimelic Acid Desuccinylase, a Potential Antibiotic Target. Plos One 2018, 13.

2. Vilar, S.; Cozza, G.; Moro, S., Medicinal Chemistry and the Molecular Operating Environment (MOE): Application of QSAR and Molecular Docking to Drug Discovery. Curr. Top. Med. Chem. 2008, $8,1555-1572$.

3. Boyd, S., Molecular operating environment. Chem. World 2005, 2, 66-66.

4. Christensen, E. M.; Patel, S. M.; Korasick, D. A.; Campbell, A. C.; Krause, K. L.; Becker, D. F.; Tanner, J. J., Resolving the Cofactor-binding Site in the Proline Biosynthetic Enzyme Human Pyrroline-5-carboxylate reductase 1. J. Biol. Chem. 2017, 292, 7233-7243.

5. Mascarenhas, R.; Le, H. V.; Clevenger, K. D.; Lehrer, H. J.; Ringe, D.; Kelleher, N. L.; Silverman, R. B.; Liu, D., Selective Targeting by a Mechanism-Based Inactivator against Pyridoxal 5 '-Phosphate-Dependent Enzymes: Mechanisms of Inactivation and Alternative Turnover. Biochemistry 2017, 56, 4951-4961.

6. Churchich, J. E.; Moses, U., 4-Aminobutyrate Aminotransferase - the Presence of Nonequivalent Binding-Sites. J. Biol. Chem. 1981, 256, 1101-1104.

7. Lee, H.; Doud, E. H.; Wu, R.; Sanishvili, R.; Juncosa, J. I.; Liu, D. L.; Kelleher, N. L.; Silverman, R. B., Mechanism of Inactivation of gamma-Aminobutyric Acid Aminotransferase by (1S,3S)-3Amino-4-difluoromethylene-1-cyclopentanoic Acid (CPP-115). J. Am. Chem. Soc. 2015, 137, 2628-2640.

8. Juncosa, J. I.; Lee, H.; Silverman, R. B., Two Continuous Coupled Assays for Ornithine-deltaaminotransferase. Anal. Biochem. 2013, 440, 145-149.

9. Moschitto, M. J.; Doubleday, P. F.; Catlin, D. S.; Kelleher, N. L.; Liu, D.; Silverman, R. B., Mechanism of Inactivation of Ornithine Aminotransferase by (1S,3S)-3-Amino-4(hexafluoropropan-2-ylidenyl)cyclopentane-1-carboxylic Acid. J. Am. Chem. Soc. 2019, 141, 10711-10721.

10. Juncosa, J. I.; Takaya, K.; Le, H. V.; Moschitto, M. J.; Weerawarna, P. M.; Mascarenhas, R.; Liu, D. L.; Dewey, S. L.; Silverman, R. B., Design and Mechanism of (S)-3-Amino-4(difluoromethylenyl)cyclopent-1-ene-1-carboxylic Acid, a Highly Potent gamma-Aminobutyric Acid Aminotransferase Inactivator for the Treatment of Addiction. J. Am. Chem. Soc. 2018, 140, 2151-2164.

11. Brosnan, M. E.; Brosnan, J. T., Hepatic Glutamate Metabolism: a Tale of 2 Hepatocytes. Am. J. Clin. Nutr. 2009, 90, 857S-861S.

12. Adams, P. D.; Afonine, P. V.; Bunkoczi, G.; Chen, V. B.; Davis, I. W.; Echols, N.; Headd, J. J.; Hung, L. W.; Kapral, G. J.; Grosse-Kunstleve, R. W.; McCoy, A. J.; Moriarty, N. W.; Oeffner, R.; Read, R. J.; Richardson, D. C.; Richardson, J. S.; Terwilliger, T. C.; Zwart, P. H., PHENIX: a Comprehensive Python-based System for Macromolecular Structure Solution. Acta. Crystallogr. D 2010, 66, 213-221.

13. Emsley, P.; Lohkamp, B.; Scott, W. G.; Cowtan, K., Features and Development of Coot. Acta Crystallogr. D Biol. Crystallogr. 2010, 66, 486-501.

14. Pettersen, E. F.; Goddard, T. D.; Huang, C. C.; Couch, G. S.; Greenblatt, D. M.; Meng, E. C.; Ferrin, T. E., UCSF Chimera--a Visualization System for Exploratory Research and Analysis. $J$. Comput. Chem. 2004, 25, 1605-1612. 
15. Gaussian 09, Revision A.02, M. J. Frisch, G. W. Trucks, H. B. Schlegel, G. E. Scuseria, M. A. Robb, J. R. Cheeseman, G. Scalmani, V. Barone, G. A. Petersson, H. Nakatsuji, X. Li, M. Caricato, A. Marenich, J. Bloino, B. G. Janesko, R. Gomperts, B. Mennucci, H. P. Hratchian, J. V. Ortiz, A. F. Izmaylov, J. L. Sonnenberg, D. Williams-Young, F. Ding, F. Lipparini, F. Egidi, J. Goings, B. Peng, A. Petrone, T. Henderson, D. Ranasinghe, V. G. Zakrzewski, J. Gao, N. Rega, G. Zheng, W. Liang, M. Hada, M. Ehara, K. Toyota, R. Fukuda, J. Hasegawa, M. Ishida, T. Nakajima, Y. Honda, O. Kitao, H. Nakai, T. Vreven, K. Throssell, J. A. Montgomery, Jr., J. E. Peralta, F. Ogliaro, M. Bearpark, J. J. Heyd, E. Brothers, K. N. Kudin, V. N. Staroverov, T. Keith, R. Kobayashi, J. Normand, K. Raghavachari, A. Rendell, J. C. Burant, S. S. Iyengar, J. Tomasi, M. Cossi, J. M. Millam, M. Klene, C. Adamo, R. Cammi, J. W. Ochterski, R. L. Martin, K. Morokuma, O. Farkas, J. B. Foresman, and D. J. Fox, Gaussian, Inc., Wallingford CT, 2016.

16. Morris, G. M.; Huey, R.; Lindstrom, W.; Sanner, M. F.; Belew, R. K.; Goodsell, D. S.; Olson, A. J., AutoDock4 and AutoDockTools4: Automated Docking with Selective Receptor Flexibility. J. Comput. Chem. 2009, 30, 2785-2791.

17. Wang, J. M.; Wang, W.; Kollman, P. A.; Case, D. A., Automatic Atom Type and Bond Type Perception in Molecular Mechanical Calculations. J Mol Graph Model 2006, 25, 247-260.

18. Sousa da Silva, A. W.; Vranken, W. F., ACPYPE - AnteChamber PYthon Parser interfacE. BMC Res. Notes. 2012, 5, 367.

19. Pronk, S.; Pall, S.; Schulz, R.; Larsson, P.; Bjelkmar, P.; Apostolov, R.; Shirts, M. R.; Smith, J. C.; Kasson, P. M.; van der Spoel, D.; Hess, B.; Lindahl, E., GROMACS 4.5: a High-throughput and Highly Parallel Open Source Molecular Simulation Toolkit. Bioinformatics 2013, 29, 845-854. 20. Towns, J.; Cockerill, T.; Dahan, M.; Foster, I.; Gaither, K.; Grimshaw, A.; Hazlewood, V.; Lathrop, S.; Lifka, D.; Peterson, G. D.; Roskies, R.; Scott, J. R.; Wilkins-Diehr, N., XSEDE: Accelerating Scientific Discovery. Comput. Sci. Eng. 2014, 16, 62-74. 